\title{
Tomasz Frydel
}

Fondation pour la Mémoire de la Shoah, Paris https://orcid.org/0000-0001-7207-5093

tfrydel@gmail.com

\section{Zwykła organizacja, nadzwyczajna przemoc państwowa. Polska policja granatowa a Zagłada we wschodniej części dystryktu krakowskiego ${ }^{1}$}

\begin{abstract}
Streszczenie
W skróconej wersji artykułu proponuję konceptualny model interakcji społecznych pozwalający przeanalizowanie postępowania „zwykłych ludzi” z Policji Polskiej (Polnische Polizei), zwanej granatową, w czasie Zagłady. Stawiam tezę, że na postępowanie funkcjonariuszy policji granatowej miały wpływ trzy kluczowe czynniki: niemiecka Policja Porządkowa, Polskie Państwo Podziemne i ludność miejscowa. Te trzy elementy stanowią swoistą triadę - strukturę wywierającą presję - w której ramach należy rozpatrywać ograniczoną sprawczość działań podejmowanych przez policję granatową. W analizie wprowadzam szeroki, regionalny kontekst trzydziestu powojennych procesów sądowych byłych członków policji granatowej i innych osób, które stanęły przed sądem bądź w których sprawie prowadzono śledztwo na podstawie dekretu z 31 sierpnia $1944 \mathrm{r}$. Obejmują one około 70 wymienionych z nazwiska policjantów granatowych. Sprawy dotyczyły przede wszystkim tzw. trzeciej fazy Zagłady, charakteryzującej się zakrojonymi na szeroką skalę od połowy 1942 do końca 1944 r. obławami na zbiegłych Żydów po przeprowadzonych przez Niemców akcjach deportacyjnych (Aktionen). W analizie skupiam się na Podkarpaciu, obejmującym siedem powiatów (Kreise) we wschodniej części dystryktu krakowskiego w Generalnym Gubernatorstwie. W artykule przedstawiam ustalenia, z których wynika, że zachowanie polskich policjantów wynikało w znacznie większym stopniu z bieżącej sytuacji niż ze względów ideologicznych. Przypadek policji granatowej świadczy o znacznie mniejszej roli antysemityzmu w spektrum motywacji sprawców. Nie neguje to jego występowania wśród policjantów ani zabójczej roli, jaką policjant odgrywał wobec ukrywających się Żydów, ale podważa spójność między postawą a zachowaniem jako wystarczającego wyjaśnienia udziału w masowych mordach.
\end{abstract}

\section{Słowa kluczowe}

policja granatowa, kolaboracja, Generalne Gubernatorstwo, sprawcy, Täterforschung, społeczeństwa pod okupacją, ruch oporu

\footnotetext{
${ }^{1}$ Artykuł ten jest uaktualnioną i skróconą wersją tekstu Ordinary Men? The Polish Police and the Holocaust in the Subcarpathian Region [w:] Mittäterschaft in Osteuropa im Zweiten Weltkrieg und im Holocaust / Collaboration in Eastern Europe during World War II and the Holocaust, red. Peter Black, Béla Rásky, Marianne Windsperger, Wien/Vienna: New Academic Press, 2019, s. 69-125. Opublikowano za zgodą wydawcy.
} 


\section{Abstract}

This (abridged) article proposes a conceptual model of social interaction to consider the behavior of the 'ordinary men' of the Polish 'Blue' Police (Polnische Polizei) and the Holocaust. It suggests three key factors shaped the actions of its rank-and-file members: the German Order Police, the Polish Underground State, and the local population. This triangular matrix of pressures represents the structure within which the limited agency of the policemen must be placed. The analysis employs a broad, regional thick description of approximately 30 postwar trial proceedings of former members of the Blue Police and others tried or investigated on the basis of the August Decree of 1944, capturing some 70 named Blue Policemen. Its emphasis is on the so-called third phase of the Holocaust, characterized by widespread manhunts for fugitive Jews following the German deportation Aktions to death camps from mid-1942 to late 1944. The geographical focus of the investigation is the Subcarpathian region, which corresponded to seven counties (Kreise) in the eastern half of District Kraków of the General Government. The article finds that the behavior of the policemen was far more situational than it was ideological in nature. The case of the Blue Police points to a less determinate role of antisemitism in the spectrum of motivation. This does not negate the presence of antisemitism in its ranks or the deadly role the policemen played in relation to Jews in hiding, but it does question the attitude-behavior consistency as a sufficient explanation for participation in mass murder.

\section{Keywords}

policja granatowa ('Blue' Police), collaboration, General Government, perpetrators, Täterforschung, occupied societies, resistance movement

O stosunkach moralnych wśród granatowej policji świadczy najlepiej następujący fakt. Policjanci Ratajczak, Gaweł i Kuczek wykryli, że u jednego z okolicznych chłopów ukrywał się pewien miejscowy Żyd, dawniej bardzo bogaty, człowiek jeszcze młody, typ bardzo rzadki, gdyż niezwykle odważny. Aresztowali oni obu, tj. żyda i 60-cioletniego chłopa, który dawał mu schronienie. Obu pobili w nieludzki sposób, chłopu, który mdlał podczas bicia, lano wiadrem wodę na głowę, a potem kazano mu ścierać jego własną marynarką. Na rozkaz Ratajczaka skazano ich na śmierć. Chłop nie mógł iść na miejsce egzekucji, więc najęto furę; żyd szedł piechotą i na głos wykrzykiwał przez miasto: „Jeszcze Polska nie zginęła!”2.

Wydaje się, że badania nad policją granatową (Polnische Polizei, PP) ${ }^{3} \mathrm{w}$ drugiej dekadzie XXI w. znalazły się na interpretacyjnym rozdrożu, podobnie jak

\footnotetext{
${ }^{2}$ Archiwum Akt Nowych w Warszawie (dalej AAN), Komenda Główna AK, Kierownictwo Walki Podziemnej, 203/VIII-2, Miesięczny przegląd sprawozdawczo-sytuacyjny danych dotyczących personaliów szczególnie gorliwych lub okrutnych przedstawicieli władz okupacyjnych oraz Polaków, wysługujących się wrogowi, 30 XI 1943 r., nr 2, punkt 3. Różne: „Niepołomice. Z granatowego bagna", k. 9.

${ }^{3}$ Przedmiotem sporów pozostaje kwestia odpowiedniego nazewnictwa tej formacji policyjnej ze względu na jej instytucjonalną dwoistość i specyfikę słownictwa lat wojny. Nosząca oficjalną nazwę Polnische Polizei im Generalgouvernement, stała się powszechnie znana jako „policja granatowa”, co było określeniem po części opisowym (ze względu na kolor mundurów), a częściowo normatywnym (co było też wyrazem powszechnej pogardy). W artykule
} 
historiografia Zagłady w połowie lat dziewięćdziesiątych. Uczestniczący w tzw. debacie Goldhagenowskiej Christopher R. Browning i Daniel J. Goldhagen wyciągnęli odmienne wnioski, badając ten sam przypadek batalionu niemieckiej Policji Porządkowej (Ordnungspolizei, Orpo), 101 Batalionu Rezerwy Policji, prowadzącego działania wymierzone w Żydów w dystrykcie lubelskim. Browning, stosując społeczno-psychologiczne podejście interpretacyjne, twierdził, że na postępowanie policjantów miała wpływ przede wszystkim dynamika sytuacji w grupie, np. następstwa brutalizacji, karierowiczostwo, konformizm wobec grupy i posłuszeństwo wobec władzy. Większość z nich stanowili mężczyźni w średnim wieku, którzy przybyli z Hamburga - niemieckiego miasta, gdzie naziści mieli słabe poparcie - oraz wywodzili się z warstwy społecznej, w której Hitler cieszył się stosunkowo małą popularnością. Nieobce im były standardy i normy polityczne $\mathrm{z}$ lat poprzedzających objęcie władzy przez nazistów. Mimo to policjanci ze 101 Batalionu zabijali w masowych egzekucjach żydowskich mężczyzn, kobiety i dzieci. Browning zakończył swoje studium słowami: „Skoro funkcjonariusze 101 Batalionu Rezerwy mogli w określonych okolicznościach stać się mordercami, to czy istnieje grupa ludzi potrafiąca tego uniknąć?"4.

Goldhagen odrzucił wielopoziomowy argument Browninga, opowiadając się za wyjaśnieniem jednoprzyczynowym, opartym na głęboko zakorzenionym niemieckim „antysemityzmie eliminacyjnym”, który jego zdaniem miał być jedynym czynnikiem motywującym ich działania ${ }^{5}$. W kolejnych badaniach, jak zaznacza Ian Rich, starano się znaleźć wyjaśnienie sytuujące się pomiędzy „spolaryzowanymi” stanowiskami w sprawie motywacji sprawców, „bezpośredniego kontekstu sytuacyjnego, i bardziej długofalowych impulsów ideologicznych"6. Po pewnym czasie Browning sam zaktualizował swoją argumentację, wskazując na istnienie w szeregach takich batalionów mniejszości „ideologicznie zmotywowanych mężczyzn”, którzy stanowili „samo jądro kadr procesu eksterminacji”, niezależnie od czynników sytuacyjnych ${ }^{7}$.

przyjmuję głównie nazwę „policja granatowa” lub „Policja Polska”, przy założeniu, że terminy te nie są synonimem przedwojennej Policji Państwowej z lat 1919-1939, ale oznaczają formację z lat 1939-1944, podporządkowaną policji niemieckiej. Niekiedy używam nazwy „Polnische Polizei”, by podkreślić, że była to instytucja Niemiec nazistowskich, a nie państwa polskiego, mimo że jej funkcjonariusze byli etnicznymi Polakami.

${ }^{4}$ Christopher R. Browning, Zwykli ludzie. 101. Rezerwowy Batalion Policji i „ostateczne rozwiq̨zanie” w Polsce, tłum. Piotr Budkiewicz, wyd. 2 popr. i uzup., Poznań: Rebis, 2019, s. 219.

${ }^{5}$ Daniel Jonah Goldhagen, Gorliwi kaci Hitlera. Zwyczajni Niemcy i Holokaust, tłum. Wiesław Horabik, Warszawa: Prószyński i S-ka, 1999, passim.

${ }^{6}$ Ian Rich, Holocaust Perpetrators of the German Police Battalions. The Mass Murder of Jewish Civilians, 1940-1942, London: Bloomsbury Academic, 2018, s. 6.

${ }^{7}$ Christopher R. Browning, Nazi Policy, Jewish Labor, German Killers, Cambridge: Cambridge University Press, 2000, s. 175; zob. również idem, „Dwadzieścia lat później [w:] Zwykli ludzie..., s. 261-329. 
Związki między policją granatową a Zagładą zaczęto badać stosunkowo niedawno. Większość badaczy podejmujących temat PP traktuje kwestię jej udziału w działaniach przeciwko Żydom raczej marginalnie ${ }^{8}$. W pracach firmowanych przez IPN zauważalna jest tendencja do rehabilitowania tej formacji ${ }^{9}$. W jedynej opublikowanej dotychczas monografii poruszającej problematykę Policji Polskiej w kontekście Zagłady Jan Grabowski odróżnia motywy jej funkcjonariuszy od motywów, jakimi kierowała się niemiecka Policja Porządkowa. W przeciwieństwie do Policji Porządkowej, pisze Grabowski:

W wypadku polskich policjantów i polskich strażaków [...] mordy dokonywane na Żydach miały głębsze korzenie. Zabójstwa popełniane często bez emocji, niejako automatycznie były możliwe dzięki głębokiej, dobrze zakorzenionej nienawiści, która wzrastała na pożywce antysemityzmu, od wieków podsycanego przez Kościół katolicki oraz indoktrynację nacjonalistyczną, przybierającą na sile od początku XX wieku. Chciwość i żądza grabieży miały więc niewątpliwy wpływ na kształtowanie postaw, ale w wypadku Polaków, morderców swoich żydowskich sąsiadów, nie były to czynniki o zasadniczym znaczeniu ${ }^{10}$.

Autor podkreśla „autonomię i sprawczość” polskiej policji, dowodząc, że ludność miejscowa darzyła zaufaniem organizację, której działalność w znacznym stopniu była przejawem woli powszechnej ${ }^{11}$.

W nieopublikowanej rozprawie doktorskiej Sylwia Szymańska-Smolkin pisze o antysemityzmie w szeregach policji granatowej, co miało być odzwierciedleniem postaw przedwojennego społeczeństwa polskiego. Wszelako zauważa, że w tych przypadkach, w których polscy policjanci zabijali Żydów „z własnej inicjatywy”, a nie na bezpośredni rozkaz władz niemieckich, „kierowali się względami innymi niż gotowością do współpracy z Niemcami, motywowaną ideologią i wspólnotą celów. Motywy te obejmowały chciwość, pragnienie materialnego zysku oraz osobiste zaangażowanie ideologiczne"12. Choć z jednej strony autorka dostrzega istotną ciągłość kadrową, organizacyjną i strukturalną między

\footnotetext{
${ }^{8}$ Więcej na ten temat zob. Adam Hempel, Pogrobowcy klęski: Rzecz o policji „granatowej" w Generalnym Gubernatorstwie 1939-1945, Warszawa: PWN, 1990; Andrii Bolianovskyi, Jacek Andrzej Młynarczyk, Leonid Rein, Oleg Romanko, Belarusian Auxiliaries, Ukrainian Waffen-SS Soldiers and the Special Case of the Polish 'Blue Police' [w:] The Waffen-SS: A European History, red. Jochen Böhler, Robert Gerwarth, Oxford: Oxford University Press, 2017, s. 169-179; Marek Getter, Policja Polska w Generalnym Gubernatorstwie 1939-1945, „Przegląd Policyjny” 1999, t. 9, nr 1/2, s. 74-91. Zob. również Andrzej Misiuk, Policja Państwowa 1919-1939. Powstanie, organizacja, kierunki działania, Warszawa: Wydawnictwo Naukowe PWN, 1996.

${ }^{9}$ Zob. np. Policja granatowa w Generalnym Gubernatorstwie w latach 1939-1945, red. Edyta Majcher-Ociesa, Tomasz Domański, Kielce: IPN, 2019.

${ }^{10}$ Jan Grabowski, Na posterunku. Udział policji granatowej i kryminalnej w zagładzie Żydów, Wołowiec: Czarne, 2020, s. 377.

${ }^{11}$ Ibidem, s. 16.

${ }^{12}$ Sylwia Szymańska-Smolkin, „Fateful Decisions: The Polish Policemen and the Jewish Population in Occupied Poland, 1939-1944", rozprawa doktorska, University of Toronto, 2017, s. 9.
} 
przedwojenną Policją Państwową a policją granatową, twierdzi również, że „policjantów pozostawiono na stanowiskach ze względów praktycznych, nie z powodu podobieństw ideologicznych z nazistowskimi Niemcami, nawet jeśli niektórzy policjanci przejawiali antysemityzm".13 Szymańska-Smolkin stwierdza większą złożoność motywacji; z jej badań wynika, że uprzedzenia wobec Żydów mogły występować u policjantów niezależnie od decyzji udzielenia pomocy czy wyrządzenia krzywdy ${ }^{14}$. Co jednak uderzające, prace obojga historyków mimo bogactwa materiału archiwalnego właściwie nie odwołują się do ustaleń i analitycznych układów odniesienia wypracowanych w ostatnich trzydziestu latach badań nad sprawcami Zagłady (Tätersforschung) ${ }^{15}$.

W artykule proponuję inne ujęcie tematu. Skupiam się bowiem na tzw. trzeciej fazie Zagłady, charakteryzującej się obławami na Żydów (zwanymi przez niemieckich policjantów Judenjagd) ukrywających się po stronie aryjskiej po zakończeniu deportacji Żydów do obozów zagłady w połowie 1942 r. Wskazuję, że postępowanie funkcjonariuszy policji granatowej kształtowały trzy kluczowe czynniki: niemiecka Policja Porządkowa, Polskie Państwo Podziemne i ludność miejscowa. Te trzy elementy stanowią swoistą triadę, strukturę wywierającą presję, i to w jej ramach należy rozpatrywać działania policji. Odwołania do owej triady nacisków nie są niczym szczególnie nowym, ale podjęcie analizy ujmującej współdziałanie tych trzech czynników razem pozwala naświetlić niekiedy paradoksalne postępowanie funkcjonariuszy policji granatowej. Ponadto interakcja tych trzech czynników, podlegających zresztą fluktuacji, odróżnia Policję Polską od policji niemieckiej pod względem motywacji do udziału w aktach skrajnej przemocy. Moim zdaniem zachowanie polskich policjantów wynikało w dużo większym stopniu z bieżącej sytuacji niż ze względów ideologicznych. Przypadek policji granatowej świadczy o znacznie mniejszej roli antysemityzmu w spektrum motywacji części sprawców Zagłady - szczególnie jeśli rozumieć go w kategoriach nienawiści etnicznej. Nie wyklucza to występowania antysemityzmu wśród policjantów ani zabójczej roli, jaką policjanci odgrywali wobec ukrywających się Żydów, ale podważa „spójność między postawą a zachowaniem" (attitude-behavior consistency) jako wystarczającego wyjaśnienia udziału w masowych mordach ${ }^{16}$.

Wnioski tu przedstawione są oparte na analizie dostępnych autorowi około 30 postępowań i procesów powojennych byłych funkcjonariuszy policji granatowej i innych osób, które stanęły przed sądami powojennej Polski na podstawie dekretu z z 31 sierpnia 1944 r. Większości z nich postawiono zarzut współudzia-

\footnotetext{
${ }^{13}$ Ibidem, s. 21.

${ }^{14}$ Ibidem, s. 22, 68, 87, 154.

${ }^{15}$ Przegląd tych badań zob. Jürgen Matthäus, Historiography and the Perpetrators of the Holocaust [w:] The Historiography of the Holocaust, red. Dan Stone, New York: Palgrave Macmillan, 2005, s. 197-215.

${ }^{16}$ Browning, Zwykli ludzie..., s. 270.
} 


\section{Studia}

łu w zbrodniach między innymi przeciwko Żydom. Biorąc pod uwagę skąpość materiałów z epoki odnoszących się do wybranego i do innych regionów okupowanej przez Niemcy Polski, takich jak raporty policyjne, w znacznej części analizy zostały wykorzystane zeznania złożone w postępowaniu sądowym. Należy jednak odnotować, że charakter tych materiałów źródłowych przesądza o pewnym ograniczeniu ich potencjału interpretacyjnego. Wszelkie próby poszukiwania wyjaśnień dotyczących zachowań na podstawie dokumentacji postępowań sądowych wiążą się nierozerwalnie z problemem, jaki stanowią źródła pierwotne, i niebezpieczeństwem powielania logiki samousprawiedliwiania się podsądnych czy rozmywania odpowiedzialności. Świadectwa byłych policjantów muszą zatem być traktowane z wielką ostrożnością, zwłaszcza zważywszy na kwestię ogólnej wiarygodności dokumentacji postępowań sądowych prowadzonych na podstawie dekretu sierpniowego, jako że została ona wytworzona w politycznie obciążonym kontekście Europy Wschodniej zdominowanej przez Związek Sowiecki okresu stalinizmu ${ }^{17}$. Trudności, jakie sprawiają tego typu badania, zapewne nigdy nie da się w pełni przezwyciężyć, ale można podjąć pewne kroki w celu zmniejszenia wspomnianego niebezpieczeństwa interpretacyjnego.

Szacuje się, że w powiatach wschodniej części dystryktu krakowskiego GG służyło około tysiąca funkcjonariuszy policji granatowej ${ }^{18}$. Dystrykt krakowski składał się z dwunastu powiatów (Kreise). Wschodnia połowa dystryktu odpowiadała podkarpackiej części dawnej Galicji Zachodniej, która mniej więcej obejmowała siedem następujących powiatów: Dębica (Debica), Jasło (Jaslo), Rzeszów (Reichshof), Krosno, Jarosław (Jaroslau), Przemyśl (Przemysl) i Sanok. W większości powiatów służyło przeciętnie dwustu policjantów niebędących Niemcami, w 25-30 posterunkach po sześciu-ośmiu funkcjonariuszy. Zakładając, że w zachodniej części dystryktu krakowskiego, gdzie znajdowała się stolica GG, służyło nieco więcej policjantów, możemy przyjąć ostrożnie skalkulowaną liczbę 2,5 tys. polskich policjantów w całym dystrykcie. Cechą charakterystyczną południowo-wschodnich powiatów Generalnego Gubernatorstwa były posterunki Ukraińskiej Policji Pomocniczej (Ukrainische Hilfspolizei) wchodzącej w skład Orpo, tam gdzie ludność ukraińska stanowiła większość, ale kwestia ta wykracza poza zakres tematyczny mojej analizy.

${ }^{17}$ Więcej na temat kontekstu procesów sądowych z dekretu sierpniowego i wykorzystania ich jako źródeł historycznych zob. Gabriel N. Finder, Alexander V. Prusin, Justice behind the Iron Curtain: Nazis on Trial in Communist Poland, Toronto: University of Toronto Press, 2018, s. 18-24, 26-29; Roman Gieroń, Półmrok. Procesy karne w sprawie przestępstw okupacyjnych popełnianych przez chłopów wobec Żydów w województwie krakowskim, Kraków: IPN, 2020; Andrew Kornbluth, The August Trials: The Holocaust and Postwar Justice in Poland, Cambridge, MA: Harvard University Press, 2021.

${ }^{18}$ Piotr Szopa, Funkcjonariusze Policji Polskiej Generalnego Gubernatorstwa w wschodnich powiatów Dystryktu Kraków w służbie Polskiego Państwa Podziemnego. Wybrane przykłady [w:] W służbie państwu i społeczeństwu: z dziejów formacji policyjnych na Podkarpaciu (19192019), Rzeszów: IPN, 2019, s. 87. 
W analizie wykorzystuję szeroki, odnoszący się do regionu tzw. opis gęsty ${ }^{19}$, w którym powołuję się na zeznania i wyjaśnienia około 70 wymienionych z nazwiska polskich policjantów ze wschodniej części dystryktu krakowskiego, czerpiąc z protokołów przesłuchań policjantów i zeznań świadków, łącząc je ze świadectwami zeznaniami ocalałych Żydów i powojennymi wspomnieniami. Poruszam również kwestię Polskiej Policji Kryminalnej (tzw. polskie Kripo) ${ }^{20}$, jeśli w danym przypadku nakładały się kompetencje obu służb.

Artykuł dotyczy przede wszystkim zwykłych funkcjonariuszy, posterunkowych, w odróżnieniu od oficerów policji. Z tego względu niniejszą analizę trudno uznać za wyczerpującą. Chociaż policjantów ujętych w tym badaniu jest stosunkowo niewielu, opis gęsty stosowany w odniesieniu do źródeł pozwala na pewne wstępne wnioski, w nadziei że dalsze badania potwierdzą je lub skorygują. Co istotne, ponieważ wielu policjantów oskarżano również o zbrodnie przeciwko Polakom i jeńcom sowieckim, umożliwia to próbę spojrzenia na analizowane przypadki w ujęciu porównawczym. Na tej samej zasadzie tekst ten sygnalizuje potrzebę przeprowadzenia odrębnej analizy historyczno-prawnej postępowań sądowych przeciwko funkcjonariuszom policji granatowej, która zawierałaby ocenę charakteru przedstawionych dowodów i typologię strategii obrony - tłumaczenia się oskarżonych wykonywaniem, takich jak wykonywanie niemieckich poleceń bądź instrukcji podziemia, obawami o własne życie czy też dbaniem o interes ludności polskiej.

\section{Władze niemieckie}

Dla zdecydowanej większości funkcjonariuszy służba w Polnische Polizei była obowiązkowa. Rekrutowano ich przede wszystkim z Policji Państwowej Drugiej Rzeczypospolitej, na podstawie odezwy wydanej 30 października 1939 r. przez szefa SS i policji Friedricha Wilhelma Krügera, nakazującej wszystkim funkcjonariuszom polskiej policji, w tym oficerom, będącym w czynnej służbie 1 września 1939 r. zgłosić się do służby w odpowiednim starostwie niemieckim do 10 listopa-

${ }^{19}$ Zob. Clifford Geertz, Thick Description: Toward an Interpretive Theory of Culture [w:] The Interpretation of Cultures: Selected Essays, New York: Basic Books, 1973, s. 3-30 [wyd. polskie: Interpretacja kultur. Wybrane eseje, tłum. Maria M. Piechaczek-Borkowska, Kraków: Wydawnictwo UJ, 2005]. Opis gęsty odnosi się do sposobu relacjonowania działań społecznych w naukach społecznych, którego celem jest opis nie tylko zachowań fizycznych, lecz także ich kontekstu, co ma ułatwić ich zrozumienie. Co istotne, opis gęsty zazwyczaj zawiera wyjaśnienia i znaczenia o charakterze subiektywnym, pochodzące od osób biorących udział w działaniach będących przedmiotem badania.

${ }^{20}$ Niemcy utworzyli Polską Policję Kryminalną w październiku 1939 r., wyłączając przedwojenną Policję Śledczą ze struktur Policji Polskiej i podporządkowując ją niemieckiej Policji Bezpieczeństwa (Sicherheitspolizei, Sipo). Policjantów szkolono w ośrodku SS w Rabce. Ich zadaniem było prowadzenie dochodzeń wyłącznie w sprawach kryminalnych z udziałem obywateli polskich. 
da pod groźbą „najsurowszej kary”21. Rezerwistów policyjnych do służby nie powoływano. 17 grudnia 1939 r. Hans Frank zatwierdził utworzenie Polnische Polizei ${ }^{22}$.

W momencie wybuchu drugiej wojny światowej Policja Państwowa liczyła 30812 funkcjonariuszy ${ }^{23}$. Około 2,5-3 tys. poległo w walkach z Niemcami w czasie kampanii wrześniowej ${ }^{24}$. Tysiące innych uciekło do Rumunii, na Litwę i Łotwę. Około 12 tys. policjantów znalazło się na terenach zajętych przez $Z S_{R R}{ }^{25}$. 0 ile Niemcy widzieli wykwalifikowanych funkcjonariuszy, których można by zwerbować do współpracy, o tyle Sowieci postrzegali policję jako zagrożenie, które należało wyeliminować. Wiosną 1940 r. NKWD zamordowało około 6 tys. policjantów i urzędników aparatu policyjnego internowanych w obozie w Ostaszkowie, straconych w Twerze i pochowanych w Miednoje ${ }^{26}$. Tych, którzy zostali osadzeni w więzieniach i mniejszych obozach na terytorium ZSRR, prawdopodobnie spotkał podobny los. Wskutek tych wydarzeń na ziemiach okupowanych przez Niemców pozostała dostępna pula rekrutacyjna w sile jednej trzeciej stanu przedwojennej Policji Państwowej, czyli około 10 tys. funkcjonariuszy. W 1941 r. niemieckie władze okupacyjne rozpoczęły kampanię rekrutacyjną, która wykraczała poza przedwojenny korpus profesjonalny. Poszukiwano szczególnie ludzi znających język niemiecki. W październiku 1941 r. w Nowym Sączu utworzono szkołę policyjną dla kandydatów do Polnische Polizei, w której podczas okupacji wyszkolono 3 tys. ochotników ${ }^{27}$. Ogólna liczba policjantów sięgnęła w 1944 r. co najmniej 12,5 tys. ludzi ${ }^{28}$. Wojnę przeżyła mniej niż połowa funkcjonariuszy Policji Państwowej Drugiej RP ${ }^{29}$.

${ }^{21}$ Odezwa wyższego dowódcy SS (Schutzstaffel) i Policji w Generalnym Gubernatorstwie dla okupowanych polskich obszarów, „Verordnungsblatt des Generalgouverneurs für die besetzeten polnischen Gebiete" (Dziennik Rozporządzeń Generalnego Gubernatora dla Okupowanych Polskich Obszarów), 2 XI 1939, nr 2, s. 16.

${ }^{22}$ Hempel, Pogrobowcy klęski..., s. 42.

${ }^{23}$ Robert Litwiński, Korpus policji w II Rzeczypospolitej. Służba i życie prywatne, Lublin: Wydawnictwo UMCS, 2007, s. 99. W liczbie tej znalazło się 876 oficerów, 27942 szeregowych policjantów oraz 1994 kandydatów do służby. Policja Państwowa obejmowała również autonomiczną Policję Województwa Śląskiego.

${ }^{24}$ Jacek Dworzecki, Policja w Polsce we wrześniu 1939 roku, „Zeszyt Naukowy [Wyższej Szkoły Bezpieczeństwa Publicznego i Indywidualnego Apeiron w Krakowie]” 2010, s. 84.

${ }^{25}$ Misiuk, Policja Państwowa..., s. 340.

${ }^{26}$ Lista ostaszkowska. Studia i materiały, red. Andrzej Misiuk, Szczytno: Wydawnictwo Wyższej Szkoły Policji, 1993, s. 15-16. Wiadomo, że z tej liczby blisko 260 funkcjonariuszy pełniących służbę na Podkarpaciu zostało zamordowanych przez reżim sowiecki (Piotr Szopa, Zbrodnia katyńska 1940. Pamięci mieszkańców powiatu strzyżowskiego zamordowanych przez Sowietów w Katyniu, Charkowie i Twerze (Kalininie), Rzeszów: IPN, 2010, s. 150-159).

${ }^{27}$ Bolianovskyi i in., Belarusian Auxiliaries..., s. 171.

${ }^{28}$ Ibidem. Szacunki w historiografii znacznie się różnią. Na przykład Dariusz Libionka podaje dane o 17-19 tys. ludzi, zob. Dariusz Libionka, Zagłada Żydów w Generalnym Gubernatorstwie. Zarys problematyki, Lublin: Państwowe Muzeum na Majdanku, 2017, s. 38.

${ }^{29}$ Marcin Kania, Losy funkcjonariuszy policji II Rzeczypospolitej Polskiej w Polsce Ludowej, „Pamięć i Sprawiedliwośćc 2012, nr 1, s. 423. 
Niemcy w znacznej mierze pozbawili nowy twór charakteru narodowego, przekształcając go $\mathrm{w}$ formację policyjną o charakterze miejskim lub gminnym. Policja Polska została podporządkowana Policji Porządkowej, w której ramach znalazły się Policja Ochronna (Schutzpolizei, Schupo), pełniąca służbę w miastach, oraz żandarmeria (Gendarmerie), rozlokowana na terenach wiejskich. Komendant Orpo był zwierzchnikiem Policji Polskiej na szczeblu powiatowym. Na Podkarpaciu posterunki w większych miastach - Rzeszowie i Przemyślu podlegały miejscowej Policji Ochronnej; pozostałe posterunki i komendy powiatowe podlegały żandarmerii ${ }^{30}$. Niemcy przeprowadzili w policji czystki, usuwając wszystkich wyższych oficerów. Policjanci mieli prawo nosić przedwojenne mundury, ale byli zobowiązani do usunięcia z czapek godła państwowego - orła, który został zastąpiony herbami powiatowymi. Policja Porządkowa zezwoliła na ograniczoną liczbę sztuk broni na posterunku policji i kontrolowała zużycie amunicji. W styczniu 1941 r. funkcjonariusze Policji Polskiej zostali zobowiązani do podpisania deklaracji, która wymagała „obowiązki służbowe w posłuszeństwie wobec niemieckiej administracji wiernie i sumiennie wypełniać", anulując „przysięgę wierności” złożoną wobec „byłego polskiego państwa lub jego organów"31. Nową formację policyjną stopniowo sprawdzano także pod kątem „rasowym". W styczniu 1942 r. policjanci byli zobowiązani zapewnić władze o braku „pochodzenia żydowskiego” do trzech pokoleń wstecz, również w odniesieniu do ich małżonków ${ }^{32}$.

Większość policjantów, o których mowa w tym tekście, zgłaszała się do służby w Policji Polskiej, powracając w okresie jesień 1939-1940 na zajmowane przed wojną stanowiska. W następnych latach kolejni mężczyźni wstępowali dobrowolnie z różnych powodów. Niektórzy odmówili wstąpienia i zaczęli się ukrywać, inni starali się uzyskać zwolnienie lekarskie ze służby ${ }^{33}$. Po wojnie wielu zwracało uwagę, że życie pod okupacją wymuszało kompromisy w sprawach fundamentalnych, a także na ograniczoną wolność wyboru. Edmundowi Czajce groziła praca przymusowa w Niemczech. Aby temu zapobiec, powołując się na

\footnotetext{
${ }^{30}$ Szopa, Funkcjonariusze Policji Polskiej..., s. 86.

${ }^{31}$ Grabowski, Na posterunku..., s. 34. Na Podkarpaciu jako przykład może posłużyć deklaracja zachowana w niemieckich aktach personalnych starszego posterunkowego (Hauptwachmeister) Władysława (Ladislaus) Malawskiego: Archiwum Instytutu Pamięci Narodowej Oddział w Rzeszowie (dalej AIPN Rz), 358/5, Akta w sprawie karnej Władysława Malawskiego, Józefa Barana i Antoniego Tumidajewicza, Akta personalne Władysława Malawskiego, 19401944, Verpflichtung/Deklaracja, Jasło, 4 I 1941 r., k. 522.

${ }^{32}$ Ibidem, Erklärung/Oświadczenie Hauptwachmeistra Ladislausa Malawskiego, Jasło, 14 I 1942 r., k. 541.

${ }^{33}$ Na przykład wiadomo, że trzech policjantów z Tuszowa Narodowego (Kreis Dębica) zdecydowało się ukrywać: Jakub Felis (lub Flis), Jan Dudzik i Józef Dudzik (AIPN Rz, 055/24, t. 3, Wykazy byłych funkcjonariuszy policji granatowej w powiecie mieleckim, Wykaz policjantów granatowych pełniących służbę z czasów okupacji niemieckiej w Tuszowie Narodowym pow. Mielec, PUBP w Mielcu, 19 VIII 1948 r., k. 90).
} 
przedwojenną służbę w Korpusie Ochrony Pogranicza (KOP), wstąpił do szkoły policyjnej w Nowym Sączu ${ }^{34}$. Służący przed wojną w policji Marian Lenartowicz zignorował wezwanie do powrotu do służby i zajął się przemytem. Został aresztowany w grudniu 1942 r. i dano mu do wyboru - jak sam przyznał - służba w Policji Polskiej lub obóz jeniecki, co z kolei oznaczałoby aresztowanie jego rodziny ${ }^{35}$. W pewnych rzadkich przypadkach obiecujący kandydaci byli przyjmowani bezpośrednio przez posterunki Policji Polskiej i tam odbywali szkolenie. Mieczysław Ożga zaczął swą pierwszą pracę w Służbie Budowlanej (Baudienst), po czym został niemieckim informatorem, pomagając zatrzymywać zbiegłych jeńców wojennych, a w 1944 r. w wieku 20 lat podjął służbę na posterunku Policji Polskiej w Jarosławiu ${ }^{36}$.

Głównym zadaniem Polnische Polizei było utrzymanie prawa i porządku w tym sensie była w znacznej mierze kontynuatorką przedwojennej Policji Państwowej. Rola ta z czasem jednak ewoluowała, gdyż coraz bardziej angażowano ją do działań niemieckiego aparatu bezpieczeństwa i terroru, co od pewnego momentu wiązało się także z udziałem w Zagładzie. Wraz z powstaniem gett i rad żydowskich (Judenraty) nadeszły niemieckie instrukcje w sprawie utworzenia policji żydowskiej, czyli Służby Porządkowej (Ordnungsdienst). Nowo powstała formacja została oddana pod nadzór Policji Polskiej.

Początkowa pensja policjanta granatowego była dość skromna, w zależności od rangi od 190 zł do 750 zł miesięcznie ${ }^{37}$, co nawet po kolejnych podwyżkach stanowiło wynagrodzenie poniżej przeciętnej. Jednocześnie Niemcy zakazali polskim policjantom podejmowania dodatkowej pracy ${ }^{38}$. Nie dziwi więc, że wykorzystywali oni swoją pozycję do uzupełnienia niskich dochodów przez nielegalny handel, łapówki i przemyt - właśnie te przestępstwa, które mieli ścigać. Po „akcjach przesiedleńczych” do obozów zagłady z 1942 r., w których przeprowadzeniu brała udział również Policja Polska, Niemcy, chcąc zwiększyć zaangażowanie funkcjonariuszy w obławy na Żydów, wprowadzili istotne zachęty,

${ }^{34}$ AIPN Rz, 358/173, Akta w sprawie karnej Edmunda Czajki, Protokół przesłuchania świadka Edmunda Czajki, Jasło, 26 IV 1956 r., k. 8-11; ibidem, Zeznanie Edmunda Czajki na rozprawie głównej przed Sądem Wojewódzkim w Rzeszowie, 25 VII 1957 r., k. 161-163. Jesienią 1942 r., po dwóch tygodniach służby w Polskiej Policji w Brzozowie (Kreis Krosno), Czajka zastrzelił rzekomego partyzanta sowieckiego.

${ }^{35}$ AIPN Rz, 107/1783, Akta karne w sprawie Władysława Malawskiego, Mariana Lenartowicza i Huberta Kuczery, Protokół przesłuchania podejrzanego Mariana Lenartowicza, Gdańsk, 13 X 1948 r., t. 1, k. 158-158v.

${ }^{36}$ AIPN Rz, 352/2, Akta w sprawie karnej przeciwko Mieczysławowi Ożdze, Sentencja wyroku Specjalnego Sądu Karnego w Rzeszowie na sesji wyjazdowej w Jarosławiu, 16 I 1945 r., k. 84-87. Ożga został skazany na śmierć i stracony przez powieszenie w Rzeszowie 28 II $1945 \mathrm{r}$.

${ }^{37}$ Grabowski, Na posterunku..., s. 39. Spośród najniższych rangą policjantów posterunkowy (Wachmeister) otrzymywał $190 \mathrm{zł}$ miesięcznie, starszy posterunkowy (Hauptwachmeister) 215 zł, przewodnik (Polizeimeister) - 240 zł. Dane na dzień 28 XI 1939 r.

${ }^{38}$ Szymańska-Smolkin, „Fateful Decisions...”, s. 57, 88. 
obejmujące do jednej trzeciej wartości mienia osób zatrzymanych ${ }^{39} .10$ grudnia 1942 r. dowódca SS i policji na dystrykt warszawski wydał Policji Porządkowej polecenie, który zostało przekazane szefostwu Policji Polskiej, by Żydów zatrzymanych poza granicami getta rozstrzeliwać na miejscu ${ }^{40}$. Podobne dyrektywy wydano też w innych dystryktach.

Warunki, w jakich funkcjonowała Polnische Polizei, sprzyjały korupcji, co stanowiło problem jeszcze w przedwojennej Policji Państwowej. Znaczny zakres władzy przyznanej formacji przez władze niemieckie, w połączeniu ze zwiększoną bezkarnością za czyny przeciwko miejscowej ludności, przyczynił się do powszechnej korupcji wśród policjantów. Dość jednolity obraz przekupnych policjantów granatowych można znaleźć w różnych źródłach. Mniejsza odpowiedzialność spowodowała też, że przemoc policjantów stała się zjawiskiem normalnym. Jako przykład może posłużyć zajście rodziny Rafów z posterunkowymi z PP w Łużnej (Kreis Jasło). 31 lipca 1941 r. do domu polskiej rodziny przybyli policjant Adam Kurowski i Piotr Januchowski. Dotarli tam w odpowiedzi na skargę złożoną przez sąsiadów, Saula Holländera i Dawida Hirschfelda, ponieważ cielę należące do Rafów pasło się na ich łące i czyniło im szkodę. Niedługo po przybyciu posterunkowi zaczęli na miejscu bić kijem i kopać Stefanię Rafę i jej 62-letnią teściową Annę Rafę, a potem drążkiem od żarna chorego umysłowo syna Anny Władysława, który stanął w ich obronie ${ }^{41}$. Policjanci przemoc usprawiedliwili tym, że rodzina „Żydowi robi krzywdę"42. Po wejściu siłą do domu w pogoni za zbiegłymi członkami rodziny Rafów posterunkowy Kurowski miał powiedzieć: „Wy myślicie, że to jest czas przedwojenny, teraz jest wojna, nam wszystko wolno"43.

Przyzwyczajeni do bezkarnego stosowania przemocy i okradania mieszkańców podczas rewizji, w czasie gdy coraz częściej byli wciągani w działania wymierzone przeciwko Żydom, wielu policjantów korzystało z nadarzających się okazji. Okradanie zatrzymanych Żydów było nieraz głównym, jeśli nie jedynym celem działań podejmowanych przez policjantów. W ten sposób policjanci granatowi nierzadko bywali głównymi beneficjentami wyłapywania ukrywających się Żydów, przejmującymi wartościowe przedmioty znalezione przy uciekinie-

${ }^{39}$ Ibidem, s. 170-171. Policjanci odnosili również korzyść w postaci nieruchomości pozostałych po deportowanych Żydach (s. 143).

${ }^{40}$ Ibidem, s. 145, 154.

${ }^{41}$ Archiwum Państwowe w Rzeszowie, Sąd Specjalny w Rzeszowie (Sondergericht Reichshof), zespół 26, sygn. 209, Dochodzenie w stosunku do funkcjonariuszy polskiej policji Adama Kurowskiego i Piotra Januchowskiego, Świadectwa lekarskie trzech członków rodziny potwierdzające ciężkie obrażenia, lek. Edward Ślęczkowski, Bobowa, 31 VII 1941 r., k. 6-8.

${ }^{42}$ Ibidem, Protokół przesłuchania Anny Rafy spisany w Prokuraturze Sądu Okręgowego w Jaśle, 2 VIII 1941 r., k. 3-3v; ibidem, Protokół przesłuchania świadka Stefanii Rafy w Sądzie Grodzkim w Gorlicach, 24 IX 1941 r., k. 17v; ibidem, Protokół przesłuchania świadka Chaima Hirszfelda w Sądzie Grodzkim w Gorlicach, 29 IX 1941 r., k. 21-21v.

${ }^{43}$ Ibidem, Protokół przesłuchania świadka Stefanii Rafy, k. 17v. 
rach żydowskich. Tym samym potwierdzało się dość powszechne w czasie wojny przekonanie o mitycznym „żydowskim bogactwie”, funkcjonujące wręcz jako samospełniająca się przepowiednia.

Wewnętrzna dynamika, zawodowe ambicje i rywalizacja miały występować na każdym stopniu policyjnej hierarchii. Decydującym czynnikiem była obecność nadzorców (Aufseher) z żandarmerii, których nierzadko delegowano w obrębie danego powiatu ${ }^{44}$. Ze względów bezpieczeństwa Policja Porządkowa z czasem zwiększyła liczbę posterunków, często nie wiązało się to jednak ze zwiększeniem liczby policjantów ${ }^{45}$. Od połowy $1943 \mathrm{r}$. w części rejonów wzmacniano posterunki, które nierzadko podlegały jednemu żandarmowi lub większej ich liczbie. Wysoki wskaźnik rotacji dowódców, nieustanne przesuwanie policjantów między stanowiskami oraz przybywanie nowych rekrutów nierzadko oznaczały, że trzon kadrowy posterunku Polskiej Policji spadł do trzech, czterech policjantów, i to oni stanowili fundament trwałych więzów koleżeństwa. Ci bardziej lojalni wobec Niemców, którzy mieli możliwość wykazania niemieckiego pochodzenia, często wyrzekali się statusu Polaka na rzecz statusu Volksdeutscha, co dawało policjantom i ich rodzinom dodatkowe przywileje. W wielu wypadkach takie decyzje torowały drogę do dalszej współpracy z władzami okupacyjnymi ${ }^{46}$.

Policja granatowa miała zasadniczo mniejszą swobodę działania niż Policja Porządkowa, chociaż po wojnie wielu byłych funkcjonariuszy stosowało linię obrony analogiczną do przyjętej przez niemieckich sprawców, powołując się na wykonywanie odgórnych poleceń. Polscy policjanci działali jednak pod stałą groźbą kary. Wszyscy policjanci musieli przynajmniej sprawiać wrażenie podległości Policji Porządkowej - było to absolutne minimum. Ci, którzy chcieli działać w interesie miejscowej ludności, nie mogli ujawniać takich zamiarów ${ }^{47}$, ale byli zmuszeni działać „dla pozoru”. Abraham Peller wspomina, jak komen-

${ }^{44}$ Bundesarchiv, Aussenstelle Ludwigsburg, B 162/7478, Akta śledcze w sprawie Drosdza, Hesslera i innych, Protokół przesłuchania podejrzanego Waltera Thormeyera (byłego szefa Gestapo w Mielcu), Prokuratura przy Sądzie Okręgowym we Fryburgu Bryzgowijskim, 9 III 1966 r., k. 73. Obsadę posterunków Policji Polskiej w powiecie dębickim stanowili nadzorujący tę formację żandarmi, którzy podlegali rotacji co dobę.

${ }^{45}$ Szymańska-Smolkin, „Fateful Decisions...”, s. 63.

${ }^{46}$ Na przykład Wincenty Wontorowski (Wątorowski) z PP w Bieczu (Kreis Jasło) zgłosił swoją przynależność do narodowości niemieckiej, podpisując pod koniec 1943 r. volkslistę (AIPN Rz, 354/9, cz. 2, Akta w sprawie karnej Wincentego Wontorowskiego, Wyrok Sądu Okręgowego w Jaśle na sesji wyjazdowej w Krośnie, 29 VIII 1947 r., k. 575). W 1948 r. Wontorowski został skazany na śmierć i powieszony.

${ }^{47}$ W raporcie BCh z okolic Krosna czytamy: „Ostatnio wyraźnie poprawia się stosunek policji granatowej do ludności polskiej, czego Niemcy nie mogą strawić. W grom[adzie] Brzozów dotychczasowego komendanta post[erunku] pol[icji] granat[owej] Kubiaka za łagodne traktowanie ludności polskiej zdegradowano do stopnia starszego posterunkowego. Na jego miejsce powołano znanego łotra Strużyńskiego" (Centralne Archiwum Wojskowe Wojskowego Biura Historycznego, Bataliony Chłopskie, Obwód IV - [krypt.] Bez, II.33.44, Gbur, Bez (Krosno), 4 IV 1944 r., k. 26-27). 
dant policji w Łużnej (Kreis Jasło) Bednarz „dostał rozkaz urządzenia obławy na Żydów” ukrywających się we wsi Moszczenica: „Dał nam znać o grożącym nam niebezpieczeństwie i opuściliśmy Moszczenicę, a nazajutrz zebrał 70 chłopów i kazał im z widłami szukać Żydów po strychach. Oczywiście nie znaleźli ani jednego". Niemniej tej gry pozorów w połączeniu z brakiem wyników nie można było prowadzić zbyt długo: „Bednarz kilka razy uratował Żydów z narażeniem własnego życia. Szantażowano go i komisarz polskiej policji Kaźmierczak oddalił go z tej wsi (Łużnej) i przeniesiono go do Jasła"48.

Według Adama Hempla od 10 do 15 procent policjantów granatowych wysłano do obozów koncentracyjnych albo zostali straceni przez Niemców ${ }^{49}$. Zbadane przypadki wskazują na szeroki zakres środków karnych wymierzanych za nieposłuszeństwo wobec władzy niemieckiej. W większości z nich niespełnienie niemieckich oczekiwań lub zajmowanie propolskiego stanowiska mogło się skończyć degradacją lub usunięciem z jednego stanowiska i przeniesieniem na inne, zwykle w obrębie tego samego powiatu (Kreis). Kiedy zastępca komendanta PP w Krzywczy (Kreis Przemyśl) Czesław Karolewski złożył żandarmerii niemieckiej skargę na swego komendanta Antoniego Sroczyńskiego, zarzucając mu „nielojalność dla Niemców” i odmowę mówienia po niemiecku „przez nienawiść dla Niemców", Sroczyńskiego w obecności kolegów i przełożonych publicznie poniżono ${ }^{50}$. W jaskrawszych przypadkach bezpośredniego nieposłuszeństwa konsekwencje były poważniejsze. Gdy kilku nowych rekrutów uciekło ze szkoły policyjnej niedaleko Dębicy, po kilku tygodniach ich zatrzymano i wysłano do Krakowa, gdzie władze niemieckie postawiły ich przed sądem. Mężczyźni zostali skazani i straceni ${ }^{51}$. Wielu policjantów próbowało porzucić służbę lub się od niej uchylało, czemu Niemcy właściwie zawsze przeciwdziałali ${ }^{52}$. Wraz z przedłu-

\footnotetext{
${ }^{48}$ Archiwum Żydowskiego Instytutu Historycznego w Warszawie (dalej AŻ̇H), 301/1649, Relacja Abrahama Pellera, Biecz, b.d., k. 2-3.

${ }^{49}$ Hempel, Pogrobowcy klęski..., s. 93.

50 „Na podstawie tego oskarżenia na odprawie komendantów posterunków w Krzywczy, w obecności około 30 policjantów, zostałem zmaltretowany przez Niemca «leutnanta», rozbrojony, zdjęto mi pas i postawiono - Leutnant kilkakrotnie wygrażał mi nad głową pięściami i rewolwerem - krzycząc nade mną, że mnie zastrzeli jak psa. [...] Od tego czasu przestałem być komendantem i dalej już pełniłem służbę jako zwykły policjant" (AIPN Rz, 359/15, Akta w sprawie karnej Antoniego Sroczyńskiego, Podanie do Prokuratury Sądu Okręgowego w Przemyślu, Wrocław, 29 VII 1949 r., k. 49). Sroczyński został wcześniej przeniesiony do Krzywczy z Kańczugi „w drodze karnej za tolerancję ludności i małe wyniki w służbie”.

${ }^{51}$ AAN, Dzienniki, kroniki, pamiętniki, 231/II-2, Przeżycia i wspomnienia partyzanta Władysława Piotrowskiego, k. 2. Owa szkoła policyjna znajdowała się na poligonie SS Heidelager (Truppenübungsplatz Heidelager) koło Dębicy i ograniczała się do rekrutowania polskich policjantów w szeregi 202 Batalionu Schutzmannschaftu. Piotrowski został przydzielony do 2 Kompanii batalionu, stacjonującej na poligonie.

52 Piotr Zemła próbował kilkakrotnie zwolnić się z policji w Brzozowie (Kreis Krosno), używając jako pretekstu złego stanu zdrowia, ale starania te nie odniosły skutku (AIPN Rz, 353/110, Akta w sprawie karnej Piotra Zemły, Protokół przesłuchania oskarżonego, Grod-
} 


\section{Studia}

żającą się okupacją Niemcy podjęli kroki mające zapobiec dezercjom, takie jak - według policjanta pełniącego służbę w Jaśle - objęcie ewidencją wszystkich członków rodziny każdego policjanta w roli zakładników, „co skrępowało swobodę działania przeważnie u żonatych"53.

W swoich powojennych relacjach oskarżeni policjanci często starali się uwypuklić elementy osobistego nonkonformizmu i działania na rzecz miejscowej ludności. Niemniej zeznania policjantów świadczą też o tym, że środki dyscyplinarne pełniły funkcję odstraszającą. Jako przykład może służyć sprawa komendanta posterunku w Czarnej (Kreis Jarosław) Jana Krupy. Jesienią 1939 r. po powrocie ze wschodu, dokąd się ewakuował w związku z działaniami wojennymi, Krupa zgłosił się do służby policyjnej w Czarnej, gdzie ponownie objął funkcję komendanta. W 1941 r. został „przeniesiony dyscyplinarnie” z Czarnej do Woli Zarczyckiej (także Kreis Jarosław) wskutek doniesienia złożonego do żandarmerii przez posterunkowego tłumacza i Volksdeutscha nazwiskiem Kolman (przesiedlony z Wielkopolski), który oskarżył go o „niechętną” postawę wobec udziału w łapankach ludzi przeznaczonych do wywiezienia do Rzeszy na roboty przymusowe ${ }^{54}$. Gdy pełnił funkcję komendanta na nowym posterunku w Woli Zarczyckiej, w 1942 r. okoliczni chłopi przyprowadzili tam sześć osób pochodzenia żydowskiego, które Krupa razem z trzema posterunkowymi zastrzelili w lesie. Podczas przesłuchania Krupa podał, iż nakłonił go do tego posterunkowy tłumacz, Volksdeutsch Marian Nowak - odpowiedzialny za składanie raportów do żandarmerii - przypominając, że „Żydów należy rozstrzelać zgodnie z zarządzeniami żandarmerii niemieckiej”. Krupa wyjaśnił, że nie miał „innego wyjścia”, ponieważ Nowak „donosi o wszystkim żandarmerii niemieckiej” w Leżajsku. Dodał, że potraktował jako „przykład” policjanta granatowego z posterunku PP w Leżajsku, który rzekomo za odmówienie wykonania poleceń niemieckich został aresztowany i rozstrzelany w Pustkowie (o czym więcej dalej) ${ }^{55}$.

Kiedy okoliczni chłopi przyprowadzili na posterunek kolejne osoby pochodzenia żydowskiego, tym razem chłopca i jego dziadka, Krupa, nie chcąc „być

ków, 18 VIII 1949 r., k. 13; ibidem, Protokół przesłuchania świadka dr. Stanisława Pilszaka, k. 39-40). Doktor Pilszak zeznał, że dostarczył Zemłowi fikcyjnych zaświadczeń potwierdzających jego zły stan zdrowia.

${ }^{53}$ AIPN Rz, 352/177, Akta Specjalnego Sądu Karnego w Rzeszowie w sprawie karnej przeciwko Adamowi Ptaszkowi, Podanie do Wysokiej Komisji Rehabilitacyjnej-Weryfikacyjnej w biurze personalnym przy Prezydium Rady Ministrów w Warszawie, Wołczyn, 23 IX 1945 r., k. 18. Według Ptaszka ewidencja objęła żony, dzieci, rodziców i rodzeństwo obojga małżonków.

${ }^{54}$ AIPN Rz, 358/170, Akta w sprawie karnej Jana Krupy, Protokół przesłuchania podejrzanego, Rzeszów, 16 XI 1955 r., k. 67. Krupa służył w Policji Państwowej od 1924 r.

55 Ibidem, Protokół przesłuchania podejrzanego Krupy, Łańcut, 19 IX 1956 r., k. 85. Walerian Hann, który pełnił funkcję powiatowego komendanta policji, rzekomo zwracał Krupie uwagę, by się strzegł, ponieważ - jak to określił - jest „obserwowany przez Niemców z uwagi na to, że nie chcę wykonywać ich rozkazów". 
zmuszony osobiście do rozstrzeliwania tych Żydów", nie wyraził zgody na ich zabicie, lecz poprosił Nowaka, żeby zadzwonił do władz i poinformował, że ujęte osoby zostaną odprowadzone na posterunek żandarmerii. Po tej okoliczności Krupa został ponownie „przeniesiony dyscyplinarnie” do Jarosławia, tym razem na skutek doniesienia Nowaka, który oskarżył komendanta o niechęć do wykonywania zarządzeń władz niemieckich. Z początkiem $1943 \mathrm{r}$. Krupa został zdegradowany ze stanowiska komendanta i służył jako zwykły policjant w komisariacie policji granatowej w Jarosławiu; był tam oddelegowany do otwierania drzwi na posterunku żandarmerii i pilnowania lokalnego banku ${ }^{56}$. Sprawa Krupy służy za przykład tego, że choć z jednej strony komendanci odgrywali ważną rolę, nadając ogólny ton działalności danego posterunku policji, policjanci pilnowali jeden drugiego. Przepisy niemieckie i lojalność podległych jednostek mogły funkcjonować jako instrument kontroli i nadzoru zarówno każdego policjanta z osobna, jak i całego posterunku.

Grabowski stwierdza, że nie natrafił na „ślad ja ki ch ko lwi ek [wyróżnienie $w$ oryginale] poważniejszych konsekwencji poniesionych przez polskiego policjanta za odmowę strzelania do Żydów" ani - przeciwnie - wyrok VI Sądu SS i Policji (któremu podlegali polscy policjanci) za zbrodnię Judenbegunstigung, czyli okazanie Żydom pomocy ${ }^{57}$. Odnalezione przeze mnie dokumenty zdają się jednak pokazywać obraz znacznie bardziej złożony. W badaniach nad Podkarpaciem jednoznaczne dowody na wymierzenie takiej kary, zwłaszcza w dokumentacji niemieckiej bądź samego Sądu SS i Policji, rzeczywiście trudno znaleźć. Niemniej w kilku przypadkach jest mowa o środkach karnych wymierzanych polskim policjantom za udzielanie Żydom pomocy. W maju 1942 r. Franciszek D. został zatrzymany przez Niemców, gdy umożliwiał Żydówce wyjście z getta warszawskiego, za co został skazany na rok więzienia i usunięty ze służby. Odbył karę w Warszawie w więzieniu przy ul. Daniłowiczowskiej, a następnie w obozie pracy przymusowej w Pustkowie ${ }^{58}$. W innym przypadku policjant nazwiskiem Brzozowski, służący w Policji Polskiej w Trześni (Kreis Dębica), wprowadził się do domu należącego wcześniej do Żydów, w którym ukrywał na strychu siedmioro żydowskich uciekinierów. Kiedy Niemcy się o tym dowiedzieli, przybył tam żandarm Albert Alscher i zastrzelił Żydów na miejscu, a Brzozowski został osadzony $\mathrm{w}$ areszcie w Tarnobrzegu ${ }^{59}$. Znany jest również przykład Bolesława Waścińskiego z Grabowa nad Wisłą (dystrykt radomski), aresztowanego w lutym 1943 r. za ukrywanie Żydówki, która uciekła z getta; około pięciu miesięcy

\footnotetext{
${ }^{56}$ Ibidem.

${ }^{57}$ Grabowski, Na posterunku..., s. 231, 379.

${ }^{58}$ Szymańska-Smolkin, „Fateful Decisions...”, s. 93. Po zwolnieniu dano mu możność powrotu do służby, ale nie zdecydował się na to. Obóz w Pustkowie znajdował się na terenie poligonu SS Heidelager; obejmował części dla jeńców sowieckich, Żydów i Polaków, służył jako główny obóz pracy przymusowej na Podkarpaciu, w którego skład wchodził obóz karny dla Polaków.

${ }^{59}$ Jan Sokół, Konspiracja nad Wisła i Sanem, Warszawa: Ludowa Spółdzielnia Wydawnicza, 1976, s. 129-130. Dalszy los policjanta jest nieznany.
} 


\section{Studia}

później znalazł się w obozie w Pustkowie ${ }^{60}$. Należy też wspomnieć o bardziej dwuznacznych przypadkach, które wymagają dalszego potwierdzenia. W archiwach można natrafić na nie do końca jasne wzmianki o policjantach granatowych ukaranych przez Niemców, choć nie wiadomo, czy kary wiązały się z udzielaniem pomocy Żydom. W jednej z takich spraw naoczny świadek wspomina o granatowym policjancie z Krakowa, który w 1943 r. został osadzony w obozie w Pustkowie, gdzie był torturowany, po czym został powieszony ${ }^{61}$.

Bardziej uderzająca historia dotyczy policjanta, który rzekomo został ukarany za bezczynność po uzyskaniu informacji o ukrywającym się Żydzie, co skończyło się osadzeniem funkcjonariusza w obozie i egzekucją. Wzmianka o tej sprawie pojawiła się w omówionej wcześniej dokumentacji procesu policjanta Jana Krupy. Twierdził on, że surowa kara wymierzona policjantowi przyczyniła się do zapanowania atmosfery strachu i wymusiła wyprzedzające posłuszeństwo wobec niemieckich poleceń. Jesienią 1942 r. w Jarosławiu odbyła się odprawa wszystkich komendantów posterunków Policji Polskiej w powiecie, na której omawiano kwestię odpowiedzialności funkcjonariuszy za brak działań wobec ukrywających się Żydów: „ostrzegano nas, że jeżeli na posterunek wpłynie doniesienie o ukrywaniu się w okolicy jakiegoś Żyda, a posterunek w związku z tym nie podejmie żadnych kroków w celu ujęcia i rozstrzelania tego Żyda, to dany posterunkowy, który takie doniesienie przyjmie, zostanie wywieziony do Oświęcimia, a nawet będzie rozstrzelany"62. Krupa przytoczył przykład przodownika Stanisława Dublągi z Leżajska (Kreis Jarosław), który zlekceważył takie doniesienie, został aresztowany i wysłany do obozu w Pustkowie. Jakiś czas później policjanci zostali oficjalnie zawiadomieni, że Dubląga został tam jako „zakładnik” rozstrzelany. Opowieść ta wymaga jednak dalszego potwierdzenia.

Przedwojenna Policja Państwowa niechętnie przyjmowała w swoje szeregi członków mniejszości etnicznych. Z wyjątkiem konwertytów Żydzi oraz przedstawiciele innych mniejszości zostali w dużej mierze wykluczeni ze struktur własnego państwa ${ }^{63}$. Nieprecyzyjne byłoby jednak uznanie formacji za zdominowaną przez antysemityzm, zwłaszcza jeśli weźmiemy pod uwagę jak surowo traktowała ona członków organizacji narodowych. Ogólnie rzecz biorąc, antyżydowskie nastroje wśród policjantów nie były niczym wyjątkowym na tle reszty społeczeństwa polskiego. Niemniej trudno wyprowadzić z tego spójną tezę o Policji Polskiej rozumianej jako „szeregowi żołnierze antysemityzmu elimi-

\footnotetext{
${ }^{60}$ Archiwum Państwowe w Radomiu, Akta Więzienia Radomskiego, W-741, sprawa Bolesława Waścińskiego, k. 1-5. Dziękuję Sylwii Szymańskiej-Smolkin za zwrócenie mojej uwagi na ten przypadek.

${ }^{61}$ AIPN Rz, Okręgowa Komisja Ścigania Zbrodni przeciwko Narodowi Polskiemu w Rzeszowie, S 2/00/Zn, Dochodzenie w sprawie zbrodni popełnionych w Pustkowie, Protokół przesłuchania świadka Jana Maksymiliana Gacy, t. 4, k. 722.

${ }^{62}$ AIPN Rz, 358/170, Protokół rozprawy głównej przed Sądem Wojewódzkim w Rzeszowie, zeznanie oskarżonego Jana Krupy, 17 XII 1956 r., k. 113.

${ }^{63}$ Szymańska-Smolkin, „Fateful Decisions...”, s. 37.
} 
nacyjnego". Nie wydaje się też, by nazistowska indoktrynacja stanowiła główną motywację policjantów. Większe znaczenie mogło mieć przekonanie, że „Polski nie ma i nie będzie" i że ludność powinna się dostosować do nowej rzeczywistości ${ }^{64}$. Warto przypomnieć, że pogląd o nieistnieniu państwa polskiego był usprawiedliwieniem, na jakie powoływał się policjant Franciszek Kłos, fikcyjny antybohater powieści Stanisława Rembeka ${ }^{65}$.

Nawet jeśli uznamy, że antysemityzm był w szeregach policji powszechny, postępowanie poszczególnych policjantów wobec poszczególnych Żydów mogło się istotnie różnić. Kajetan Paprocki, który w 1939 r. przybył do Rzeszowa z Katowic, został początkowo powołany do Policji Polskiej, potem wyznaczono go na stanowisko szefa polskiego Kripo w Rzeszowie. Według raportu operacyjnego Urzędu Bezpieczeństwa „żył w złych stosunkach” z żoną, która miała romans. Paprocki uciekł z Rzeszowa razem z Niemcami, a w drodze towarzyszyła mu jego kochanka pochodzenia żydowskiego (nazwiskiem Bajbach), którą kiedyś „zabrał z getta rzeszowskiego”. Po wyzwoleniu zamieszkali razem w Łodzi ${ }^{66}$. Podobnie policjant granatowy Józef Chlebek z Dynowa (Kreis Krosno) przechowywał w domu swego brata Władysława Żydówkę Chanę Szrajer. Chlebek był zaręczony z Izabelą Kędzierską, ale kiedy zaszła w ciążę, miał zerwać zaręczyny i wraz ze Szrajerową planował ucieczkę do Lwowa, wykorzystując w tym celu dokumenty tożsamości swojej narzeczonej. Gdy w lecie 1943 r. Kędzierska dowiedziała się o tych planach, zadenuncjowała ich do komendanta żandarmerii w Dynowie, niejakiego Kraumera. Szrajer została aresztowana i następnego dnia rozstrzelana przez żandarmów, aresztowanemu Józefowi Chlebkowi udało się zaś po tygodniu zbiec z więzienia w Brzozowie i dożyć wyzwolenia w ukry$\mathrm{ciu}^{67}$. Przykłady te pokazują nie tylko, że ludzie zakochani są w stanie dokonać różnych rzeczy, ale że antyżydowskie uprzedzenia mogą w znacznym stopniu istnieć niezależnie od zachowań.

${ }^{64}$ Symptomatyczne są słowa przypisane plutonowemu PP w Lisiej Górze (Kreis Tarnów) Władysławowi Rzepie, który podczas konfiskowania towaru przyłapanemu przemytnikowi powiedział: „nie myśl sobie, że to jest za Polski, to jest za Niemców, abyś mógł handlować, bo Polski już nie ma i nie będzie" (Archiwum Instytutu Pamięci Narodowej Oddział w Krakowie, 502/101, Akta Specjalnego Sądu Karnego w Krakowie w sprawie karnej przeciwko Władysławowi Rzepie, Protokół przyjęcia ustnego zawiadomienia Władysława Barwacza o przestępstwie, Posterunek MO w Lisiej Górze, 8 III 1945 r., k. 5).

${ }^{65}$ Stanisław Rembek, Wyrok na Franciszka Kłosa, Warszawa: Pax, 1977, s. 33-34. Rembek oparł swoją opowieść na autentycznej historii policjanta o tym samym nazwisku z Grodziska Mazowieckiego (dystrykt warszawski).

${ }^{66}$ AIPN Rz, 042/2126, Dochodzenie operacyjne w sprawie karnej Kajetana Paprowskiego, Streszczenie materiałów dotyczących Paprockiego Kajetana, byłego szefa Kripo w Rzeszowie, oparte na podstawie informacji dostarczonej przez byłego informatora ps. „Otto”, opracował S. Syzdek, 16 VII 1956 r., k. 14.

${ }^{67}$ AIPN Rz, 353/31, Akta w sprawie karnej Izabeli Kędzierskiej, Protokół przesłuchania świadka Wojciecha Chlebka (ojca Józefa Chlebka), Dynów, 24 VII 1949 r., k. 13-13v; ibidem, Protokół przesłuchania podejrzanej Izabeli Kędzierskiej, Dynów, 24 VII 1949 r., k. 22-23. 


\section{Studia}

Istniała jednak zdecydowana różnica między przypadkami odmowy udziału w prześladowaniach Polaków a odmową uczestnictwa w prześladowaniach Żydów. Wprawdzie próg uczestnictwa w działaniach antyżydowskich był znacznie niższy, niemniej stanowiło ono element tego samego systemu nacisków na policjantów. W Jedliczach (Kreis Krosno) polski policjant Ludwik Ostrowski odmówił wykonania rozkazu przełożonego - strzelania do uciekającego Władysława Wajdy, który był wyznaczony do wywiezienia na roboty przymusowe w Rzeszy, co spowodowało, że komendant Policji Polskiej „wyrwał mu karabin z ręki i strzelił w kierunku Wajdy". ${ }^{68}$ Takie postępowanie i w zasadzie łagodne odnoszenie się Ostrowskiego do miejscowych miały ten skutek, że jego przełożeni nie angażowali go do poważniejszych akcji. Bardziej powszechne zjawisko odmowy udziału w działaniach antypolskich w przeciwieństwie do działań przeciw Żydom odzwierciedlało podziały narodowościowe w Drugiej Rzeczypospolitej oraz poczucie solidarności wspólnotowej, która z tych podziałów wyrosła, a te z kolei pod rządami ludobójczego i rasistowskiego reżimu wzmocniły się i nasiliły.

\section{Podziemie polskie}

Związki między granatową policją a podziemiem do dziś czekają jeszcze na gruntowne, systematyczne zbadanie. Szacuje się, że 20-30 procent polskich policjantów współpracowało z podziemiem niepodległościowym ${ }^{69}$. Państwo Podziemne stworzyło również własną formację policyjną - Państwowy Korpus Bezpieczeństwa $(\mathrm{PKB})^{70}$. Ogólnie rzecz biorąc, ruch oporu nie był w stanie wystąpić frontalnie przeciwko niemieckiej władzy. Mógł natomiast osłabić oddziaływanie niemieckiego terroru przez neutralizację zidentyfikowanych donosicieli i ograniczenie aktów represji. Dlatego zastosowano politykę spełniania absolutnego minimum wymagań stawianych przez Niemców mieszkańcom wsi przy minimalnym poświęceniu ze strony miejscowej ludności. Policjant miał decydujące znaczenie dla podziemia, zbierając informacje umożliwiające takie postępowanie. Stefan Dąmbski, żołnierz grupy dywersyjnej i wykonawca wyroków w podobwodzie AK Rzeszów-Południe, przywołał we wspomnieniach rolę wtyczek

${ }^{68}$ AIPN Rz, 353/243, Akta w sprawie karnej Ludwika Ostrowskiego, Protokół rozprawy głównej przed Sądem Apelacyjnym w Rzeszowie na sesji wyjazdowej w Krośnie, Zeznanie świadka Edwarda Gorczyca, 6 XI 1950 r., k. 128; ibidem, Zeznanie świadka Wojciecha Kłosowicza, k. 128.

${ }^{69} \mathrm{Na}$ temat owych 20-30 procent zob. Maciej Korkuć, Niemiecka Polnische Polizei. Historyczny i państwowo-prawny kontekst funkcjonowania granatowej policji w Generalnym Gubernatorstwie 1939-1945 [w:] Policja granatowa..., s. 50. Na temat 30 procent zob. Szymańska-Smolkin, „Fateful Decisions..., s. 23.

${ }^{70}$ Bolianovskyi i in., Belarusian Auxiliaries..., s. 177. Spośród 8400 członków PKB w październiku 1943 r., 2040 stanowili szeregowi funkcjonariusze, a 100 oficerowie policji granatowej. 
w Gestapo i policji granatowej: „W większości wypadków byliśmy ostrzegani przez tych panów o nadchodzących łapankach do Niemiec lub też wsypach. Ci ludzie byli dla nas na wagę złota. Nie było ich wielu". Jedną z takich drogocennych wtyczek był „nie kto inny, jak sam komendant polskiej policji mundurowej w Tyczynie" (Kreis Rzeszów) ${ }^{71}$. W czasie wojny informacje wywiadowcze pochodzące z takich źródeł stanowiły ważny mechanizm przetrwania ludności miejscowej.

Wielu policjantów wstąpiło do odtworzonej po działaniach wojennych policji na polecenie rządu RP na uchodźstwie lub struktur podziemia. Wspomniany wcześniej Lenartowicz przypomniał sobie, że na jego decyzję powrotu do służby wywarło wpływ przemówienie radiowe gen. Władysława Sikorskiego, premiera rządu RP na uchodźstwie, który 28 grudnia 1940 r. wzywał byłych urzędników państwowych do ponownego zajmowania swoich stanowisk w celu ochrony ludności ${ }^{72}$. Bronisław Stafin oświadczył, że powrócił na swój przedwojenny posterunek w Szerzynach (Kreis Jasło) na polecenie Związku Walki Zbrojnej, do którego wstąpił w 1940 r.; później dostał od Batalionów Chłopskich polecenie pozostania w służbie ${ }^{73}$.

Czynnik wymuszający, jakim był obowiązkowy powrót do służby, działał równolegle z czynnikiem przyciągającym ze strony polskiego rządu na uchodźstwie i utworzonych na początku okupacji struktur konspiracyjnych, które zachęcały policjantów do ponownego wstąpienia do służby w celu zbierania informacji, co miało chronić społeczeństwo polskie przed represjami ze strony okupanta. W wypadku policjantów związanych z ruchem oporu łącznicy podziemia często koordynowali swoje działania, takie jak wstępna decyzja o tym, czy wstąpić do służby bądź starać się o awans. Podziemie mogło również wywierać presję na policjantów nieskorych do współpracy, grożąc im wyrokiem śmierci za odmowę. Działalność propagandowa ruchu oporu w postaci ostrzeżeń, artykułów publikowanych w prasie podziemnej oraz czarnych list policjantów miała na celu zniechęcenie policjantów do angażowania się $\mathrm{w}$ to, co podziemie uznawało za kolaborację $^{74}$. W placówkach Policji Polskiej wywoływało to dodatkowe napięcia.

\footnotetext{
${ }^{71}$ Stefan Dąmbski, Egzekutor, Warszawa: Ośrodek Karta, 2010, s. 18.

${ }^{72}$ AIPN Rz, 107/1783, Protokół przesłuchania podejrzanego Mariana Lenartowicza, t. 1, k. $158 \mathrm{v}$.

${ }^{73}$ AIPN Rz, 353/258, Akta w sprawie karnej Bronisława Stafina, Protokół przesłuchania podejrzanego, Rzeszów, 15 III 1950 r., k. 23; ibidem, Protokół przesłuchania świadka Jana Miłoraja, ps. „Sowiński”, Wronki, 21 VII 1950 r., k. 122; ibidem, Pismo adwokata do Sądu Apelacyjnego w Rzeszowie, 26 IX 1950 r., k. 137.

${ }^{74}$ W okresie największego nasilenia „akcji wysiedleńczych” w dystrykcie krakowskim „Biuletyn Informacyjny Małopolski” ostrzegał: „Przypo min a my: Nie zgłaszać się do Polskiej Policji. Wedle faktów stwierdzonych w ostatnich czasach, wielu nowo zgłoszonych wciela się do specjalnej służby pomocniczej niem[ieckiej], wywozi dla przeszkolenia do obozu w Dębicy [prawdopodobnie obóz w Pustkowie - T.F.], gdzie nierzadko każą «uczyć się» strzelania do żydów. Formacje polskie są używane do walki z desantami i partyzantką, do nie-
} 


\section{Studia}

W innych przypadkach policjanci, którzy wykazywali nadmierny „entuzjazm" w wykonywaniu obowiązków powierzonych im przez okupanta, mogli być karani przez podziemne sądownictwo, które wiosną $1943 \mathrm{r}$. zaczęło działać energicznie. Jeśli policjant stanowił zagrożenie dla podziemia, wyroki były wydawane przez sądy wojskowe. Począwszy od stycznia 1943 r. wyroki wydawały sądy cywilne, jeśli postępowanie policjanta stanowiło zagrożenie dla cywilów (np. udział w obławach na roboty przymusowe, wszelkie formy „nadgorliwości”, uczestnictwo w egzekucjach, w tym Żydów).

Na początku 1943 r. Kierownictwo Walki Cywilnej Polskiego Państwa Podziemnego wydało „Pierwszą czarną listę Polskiej Granatowej Policji” w dystrykcie krakowskim, w której przed wykonaniem wyroków wymieniono 38 policjantów skazanych na śmierć przez sądownictwo podziemne ${ }^{75}$. Gdy trzech granatowych policjantów popełniło błąd w rzeszowskiej restauracji, prosząc tam o dokumenty wspomnianego Stefana Dąmbskiego i dwóch zakonspirowanych kolegów, ci ostatni otworzyli ogień i zabili trzech policjantów na miejscu, w tym jednego, który pracował dla AK, o czym Dąmbski dowiedział się dwa tygodnie po fakcie ${ }^{76}$. Policjantów należących do Armii Krajowej nie ominęły środki dyscyplinarne ${ }^{77}$. Wschodnia połowa dystryktu krakowskiego pokrywała się z czterema inspektoratami podokręgu AK Rzeszów. Sądy państwa podziemnego skazały w tym podregionie na śmierć 33 funkcjonariuszy Policji Polskiej i Polskiej Policji Kryminalnej, co stanowiło około 7 procent około 500 wydanych tam wyroków śmierci ${ }^{78}$. Jak się okazało, w europejskim imperium policyjnym Heinricha Himmlera przynależność do Polnische Polizei była poważnym zagrożeniem dla życia. Zbieg poleceń niemieckich, nakazujących uczestnictwo w morderczych operacjach, w połączeniu z karą ze strony podziemia przekładał się na wysoką liczbę ofiar wśród policjantów granatowych - najwyższą spośród wszystkich mundurowych formacji policyjnych w Generalnym Gubernatorstwie ${ }^{79}$.

bezpiecznych obław po lasach. Z obozu w Dębicy już się wycofać nie można” (Nakazy chwili, „Biuletyn Informacyjny Małopolski”, 13 VIII 1942, nr 23, s. 4). Jestem wdzięczny Alicji Jarkowskiej-Natkaniec za zwrócenie na to mojej uwagi.

${ }^{75}$ AAN, Armia Krajowa, 203/III-117, k. 23.

${ }^{76}$ Dąmbski, Egzekutor..., s. 18.

${ }^{77}$ Bolianovskyi i in., Belarusian Auxiliaries..., s. 179. W odniesieniu do wcześniej wspomnianego Bronisława Stafina „Bociana” Józef Miłoraj „Sowiński” zeznał, że meldunki o „nadużyciach" Stafina napływały często. 31 VII 1944 r. Miłoraj wraz z grupą 12 ludzi został wezwany przez tarnowskie dowództwo AK do natychmiastowego wykonania kary chłosty (40 „na tyłek”) na policjancie. Kara ta jednak nie została wykonana z powodu nadejścia frontu - zamieniono ją na przymusowe wstawienie się Stafina w szeregi oddziału; pełnił tam funkcję instruktora wojskowego do czasu nadejścia Armii Czerwonej.

${ }^{78}$ Ogółem 33 odnotowanych w: Szopa, Funkcjonariusze Policji Polskiej..., s. 103. Surowe dane na temat 26 wyroków spośród 499 w: Piotr Szopa, „W imieniu Rzeczypospolitej...” Wymiar sprawiedliwości Polskiego Państwa Podziemnego na terenie Podokręgu AK Rzeszów, Rzeszów: IPN, 2014, s. 464-542.

${ }^{79}$ Bolianovskyi i in., Belarusian Auxiliaries..., s. 179. 
Żadne dokumenty wytworzone przez podziemie nie pozwalają stwierdzić, że zabijanie Żydów, których formalnie należało postrzegać jako obywateli polskich, zostało usankcjonowane przez dowództwo podregionu AK Rzeszów. W praktyce jednak ochrona etnicznych Polaków miała wyższy priorytet niż ochrona etnicznych Żydów. Owa domniemana preferencja dla członków własnej wspólnoty narodowej czy etnicznej, w połączeniu z imperatywem ochrony organizacji podziemnej nierzadko wpływała na decyzje miejscowego kierownictwa w odniesieniu do ukrywających się Żydów. Wydaje się, że policjanci mający powiązania z podziemiem częściej udzielali Żydom pomocy, choć inicjatywa zwykle przychodziła z dołu. Decydującą rolę odgrywało zróżnicowanie indywidualnych postaw. Znajdziemy więc policjantów zaangażowanych $w$ działania przychylne wobec ludności żydowskiej. Na przykład dowiedziawszy się o zbliżającej się likwidacji getta gorlickiego, szef Kripo w Gorlicach (Kreis Jasło) Jan Fereński ps. „Sęp” powiadomił swojego dowódcę, przewodniczącego Rady Żydowskiej i inne osoby, co umożliwiło ucieczkę wielu Żydom ${ }^{80}$. Podobnie, i to głównie ze względu na kierowniczą funkcję Józefa Laska „Orlicza” w strukturach podziemia, posterunek PP w Bobowej (Kreis Jasło) pod jego komendą jest klasą sam dla siebie. Obsadę posterunku stanowili niemalże w całości członkowie Armii Krajowej, aktywnie pomagający prześladowanym Polakom i Żydom, z których część schroniła się w budynku policji ${ }^{81}$. Natomiast zaledwie $30 \mathrm{~km}$ na wschód od Bobowej w tym samym powiecie policjanci z Biecza, którzy nie mieli żadnych znanych nam związków z podziemiem, należeli do najbardziej aktywnych w działaniach antypolskich i antyżydowskich ${ }^{82}$.

W rzeczywistości zabijanie Żydów przez policjantów nie zawsze kłóciło się $\mathrm{z}$ etosem ochrony „członków narodu polskiego”. Komendant posterunku PP w Radomyślu Wielkim (Kreis Dębica) Jan Pielach zwracał uwagę na szczegółowe instrukcje miejscowych struktur Armii Krajowej w tym zakresie. Pielach został przesiedlony z rodziną z Wielkopolski w $1940 \mathrm{r}$. i wstąpił do szkoły policyjnej w Nowym Sączu. Jako policjant zdobył zaufanie żandarmerii, a pod koniec oku-

${ }^{80}$ Michał Kalisz, Elżbieta Rączy, Dzieje społeczności żydowskiej powiatu gorlickiego podczas okupacji niemieckiej 1939-1945, Rzeszów: IPN, 2015, s. 97. Początkowo Fereński służył jako komendant PP w Gorlicach.

${ }^{81}$ Ibidem, s. 98-101; Michał Kalisz, Józef Laska - policjant i żołnierz konspiracji, „Rocznik Sądecki” 2011, t. 39, s. 243-253. Laska pełnił różne funkcje kierownicze w ZWZ-AK, w tym dowódcy Państwowego Korpusu Bezpieczeństwa oraz szefa wywiadu gorlickiej AK. Wśród wielu akcji Laski znalazły się również koordynowanie przerzutu Żydów na Węgry, próba przewiezienia 25 tarnowskich Żydów w czasie akcji w Bobowej oraz wytwarzanie fałszywych dokumentów tożsamości dla Żydów (Kennkarte). Godną uwagi postacią, która znalazła się pod opieką grupy Laska i została wcielona do jej struktur, był lwowski matematyk i teoretyk gier dr Hugo Steinhaus.

${ }^{82}$ Krzysztof Przybyłowicz, Żydzi Biecza. Historia i zagłada, Tuchów: Mała Poligrafia Redemptorystów, 2015, s. 150-153. 
pacji zgodził się na współpracę z podziemiem ${ }^{83}$. W czasie swego powojennego procesu zeznał, że „miał odpowiednie instrukcje władz organizacji podziemnej, by likwidować Żydów, jeżeli zachodziło prawdopodobieństwo oskarżenia przez nich Polaków, którzy im poprzednio pomagali" ${ }^{\prime 4}$. W wypadku policjantów, którzy w taki czy inny sposób byli związani z ruchem oporu, obojętność na śmierć Żydów wiązała się częściowo z nadrzędnym imperatywem penetracji niemieckich struktur policyjnych i akceptowalnym poziomem „strat ubocznych" (collateral damage) w stosunku do korzyści odniesionych przez organizację. W praktyce oznaczało to czasem tolerancję wobec funkcjonariuszy w zakresie ich działań w ramach formacji okupacyjnych.

Można to wykazać w trzech podjętych przez ruch oporu próbach zwerbowania policjantów w różnych częściach Podkarpacia. Pierwsza sprawa dotyczy dwudziestoletniego Rudolfa Probsta „Wekslera”, do którego zwrócił się szef dowództwa okręgu AK, by podpisał Deutsche Volksliste, co awansowało go do uprzywilejowanego statusu Volksdeutscha, przez co stał się poszukiwanym kandydatem do pracy w sanockim Gestapo. Probstowi udało się zdobyć pracę tłumacza, dzięki czemu zyskał dostęp do kartoteki informatorów Gestapo i ujawnił w zasadzie całą lokalną sieć agenturę dowództwu $\mathrm{AK}^{85}$. Operacja ta została uznana za duży sukces, który znacznie przyczynił się do poprawy bezpieczeństwa miejscowej społeczności. W drugim przypadku wywiad podziemia próbował osiągnąć ten sam cel z tłumaczem mieleckiego Gestapo (Kreis Debica) Rudolfem Zimmermannem, lecz zakończyło się to niepowodzeniem. W dalszym okresie okupacji Zimmermann okazał się niestrudzonym „katem” Polaków i Żydów w okolicy Mielca, a następnie dostał od AK dwa wyroki śmierci, podjęto też jedną próbę otrucia go ${ }^{86}$. Próba zwerbowania przez podziemie była zrozumiała, ponieważ udane odwrócenie policjanta mogło przynieść wymierne rezultaty, tak jak w wypadku Probsta. Jak pokazuje jednak przypadek Zimmermanna, nierzadko kierownictwo podziemia było gotowe wchodzić w konszachty z podejrzanymi osobami, tolerując do pewnego stopnia straty uboczne, rosnące ogólnie rzecz biorąc wraz z pozycją zajmowaną w hierarchii policyjnej.

W trzecim przypadku - polskiego policjanta Wilhelma Jakiego ps. „Korab” - struktury podziemia tolerowały poświęcanie Żydów dla ochrony polskiej zbiorowości wiejskiej. Powiązania Jakiego z podziemiem sięgały pierwszych miesięcy okupacji. Jako przedwojenny oficer Policji Państwowej w Warszawie wziął udział w obronie stolicy w czasie kampanii wrześniowej i został wtedy

${ }^{83}$ USC Shoah Foundation, Visual History Archive, 48515, Wywiad z Antonim Balarynem (ur. 1926), 1998 r., odc. 93.

${ }^{84}$ AIPN Rz, 32/1, Akta w sprawie karnej Jana Pielacha, Protokół rozprawy głównej przed Sądem Apelacyjnym w Rzeszowie, Zeznanie oskarżonego Jana Pielacha, 20 III 1950 r., k. 30.

${ }^{85}$ Szopa, „W imieniu Rzeczypospolitej...” Wymiar sprawiedliwości..., s. 87-91.

${ }^{86}$ Andrzej Krempa, Zagłada Żydów mieleckich, Mielec: Muzeum Regionalne w Mielcu, 2013, s. 25-26. 
ranny. W czasie leczenia szpitalnego Jaki nawiązał kontakty z pierwszymi strukturami ruchu oporu i został wkrótce zwerbowany przez Tajną Armię Polską, w której jako policjant nowo utworzonej Polnische Polizei pełnił funkcję zwiadowczą, zbieracza broni i amunicji oraz osłony przy różnych akcjach ${ }^{87}$. W grudniu 1942 r. został powiadomiony o przeniesieniu do komendy powiatowej Policji Polskiej w Dębicy, co podczas przesłuchania przez Urząd Bezpieczeństwa przypisywał interwencji rodziny, która nakłaniała go do podpisania volkslisty, czego - jak twierdził - odmówił ${ }^{88} .1$ stycznia 1943 r. zgłosił się do żandarmerii w Dębicy i podjął tam pracę jako tłumacz. Nadal opierał się naciskom, by podpisać volkslistę, tym razem ze strony swego przełożonego Gerharda Buchholza. Fakt, że później również opierał się tym naciskom, może stanowić częściowe wyjaśnienie, dlaczego pozostał polskim policjantem w szeregach żandarmerii, większość służby pełniąc w PP Wielopole Skrzyńskie ${ }^{89}$. W służbie pozostał do 24 lipca $1944 \mathrm{r}$.

Po nawiązaniu kontaktu z miejscowymi strukturami ruchu oporu Jaki szybko stał się cenionym współpracownikiem dębickiej AK. Wszedł w skład podziemnych struktur w wiosce Mała ${ }^{90}$. Po ogłoszeniu wyroku w powojennym procesie w piśmie skierowanym do Ministerstwa Sprawiedliwości w Warszawie twierdził, że jego przeniesienie do Dębicy zostało zaaranżowane przez dowództwo AK w Warszawie ${ }^{91}$. Był szczególnie przydatny przy likwidowaniu niemieckich konfidentów oraz osób uznanych przez miejscowe struktury AK za elementy niebezpieczne, działając pod pozorem wykonywania czynności policyjnych. Gdy Niemcy zaczęli go podejrzewać o działalność w podziemiu, zabrał całą broń i amunicję z posterunku PP w Wielopolu, uciekł do lasu, gdzie dołączył do kompanii „Pęka”; we wrześniu i w październiku 1944 r. dowodził plutonem w walkach z byłymi kolegami z żandarmerii.

${ }^{87}$ Zgodnie z relacją złożoną przed śledczymi MO 15 XII 1939 r. Jaki wyszedł ze szpitala, a następnego dnia wrócił do służby w policji. Na początku 1940 r. został powołany do TAP przez Tadeusza Dobrowolskiego „Profesora”. Wiosną 1942 r. przeniesiono go na 13 Komisariat policji przy ul. Daniłowiczowskiej, gdzie pozostał do końca roku (AIPN Rz, 353/278, Akta w sprawie karnej Wilhelma Jakiego, Własne zeznanie, Rzeszów, 12 VIII [1950 r.], k. 22; ibidem, Protokół przesłuchania podejrzanego Wilhelma Jakiego, Rzeszów, 14 VIII 1950 r., k. 41-42).

${ }^{88}$ Jaki urodził się w 1911 r. w Czerminie (Hohenbach), niedaleko Mielca (Kreis Dębica), w rodzinie etnicznie niemieckiej i protestanckiej. Jego matka Maria (z domu Bauer), brat Fryderyk, i siostra Luiza podpisali volkslistę.

${ }^{89}$ AIPN Rz, 353/278, Protokół przesłuchania podejrzanego Jakiego, Rzeszów, 14 VIII 1950 r., k. 42; ibidem, Własne zeznanie, Rzeszów, 12 VIII 1950 r., k. 22. Dodał, że Buchholz nakłaniał go do przejścia do żandarmerii, a nawet groził deportacją do Auschwitz względnie więzieniem. Następnie Jaki został podwładnym Roberta Urbana, niesławnego żandarma z Dębicy. W tym okresie PP w Wielopolu Skrzyńskim kierował żandarm Emil Bystroń.

${ }^{90}$ Ibidem, Oświadczenie Wilhelma Jakiego przed Wojewódzkim Urzędem Bezpieczeństwa Publicznego w Poznaniu, 24 IV 1947 r., k. 99.

${ }^{91}$ Ibidem, Prośba Wilhelma Jakiego do Ministerstwa Sprawiedliwości w Warszawie, Biuro Skarg i Zażaleń (odpis), Strzelce Opolskie (pod aresztem), grudzień 1956 r., k. 502. 


\section{Studia}

Oprócz czynów o charakterze patriotycznym Jaki ponosił także odpowiedzialność za zabicie w regionie kilkunastu Żydów. Podobnie jak w wypadku zabijania cywilów uznanych za donosicieli, mordowanie Żydów również uzasadniał koniecznością wojskową. Jesienią 1943 r. zastępca dowódcy PP w Wielopolu Emil Bystroń, rzekomo pochodzący z Czechosłowacji, przedstawił swemu przełożonemu w Dębicy plan przeprowadzenia pacyfikacji z udziałem miejscowych oddziałów SS z Pustkowa w dwóch wsiach położonych w pobliżu Wielopola Skrzyńskiego, po otrzymaniu donosu o ukrywaniu Żydów i o znacznej liczbie napadów rabunkowych. Jaki odpowiedział kontrpropozycją oddelegowania go na posterunek w Wielopolu, oddania mu pod komendę jednego granatowego, Józefa Kapelusza, i pozwolenia, by działał samodzielnie przeciw pojedynczym ukrywającym się Żydom. Zgodnie z tą logiką w ten sposób ocalałyby pobliskie wsie $^{92}$. Buchholz zaakceptował tę propozycję. W rzeczywistości to, co utworzył Jaki, miało być Jagdkommando, czyli specjalną jednostką operacyjną, której celem było ujawnianie i zabijanie ukrywających się Żydów ${ }^{93}$. Jego taktyka polegała na wynajdywaniu Polaków ukrywających Żydów i werbowaniu ich na informatorów przemocą fizyczną lub groźbami, co pozwoliło mu sformować niewielką sieć konfidentów ${ }^{94}$. W 1950 r. Jakiego uznano za winnego współudziału w zabójstwie piętnastu „osób narodowości żydowskiej” oraz trzech „narodowości polskiej” i skazano na karę śmierci ${ }^{95}$.

Werbując funkcjonariuszy policji i administracji niemieckiej, podziemie dbało o własną reputację organizacyjną. Zależało to również od okoliczności lokalnych i charakteru miejscowych przywódców. Ze względu na ograniczoną liczbę źródeł archiwalnych dotyczących dębickiej AK nie jest jasne, czy działania Jakiego wywołały jakiekolwiek spory w szeregach podziemia. Podczas przesłuchania przez oficera śledczego WUBP w Rzeszowie Jaki przyznał, że miejscowe dowództwo było świadome jego działań. W niektórych przypadkach zabijanie zbiegłych Żydów miało się odbywać wręcz na polecenie lokalnych struktur podziemia. Twierdził, że od dowódcy placówki AK w Brzezinach Stanisława Lachmana ps. „Zan” otrzymał polecenie, by zlikwidować Żydówkę nazwiskiem Szwarc i jej trzynastoletnią córkę; „konieczność” dokonania zabójstwa uzasad-

${ }^{2}$ Ibidem, Protokół przesłuchania podejrzanego Wilhelma Jakiego (odpis), Rzeszów, 31 VIII 1950 r., k. 72-73; ibidem, Protokół przesłuchania podejrzanego Jakiego (odpis), Rzeszów, 5 IX 1950 r., k. 90-91.

${ }^{93}$ Ibidem, Protokół przesłuchania świadka Jana Chmury, byłego sołtysa wsi Brzeziny (odpis), Wielopole Skrzyńskie, 14 IX 1950 r., k. 148-149.

${ }^{94}$ Ibidem, Protokół przesłuchania podejrzanego Jakiego, k. 73; ibidem, Protokół przesłuchania podejrzanego Stanisława Wodzisza (odpis), Rzeszów, 2 IX 1950 r., k. 83-84; ibidem, Protokół przesłuchania świadka Józefa Piontka (odpis), Wielopole Skrzyńskie, 14 IX 1950 r., k. 131.

95 Ibidem, Wyrok Sądu Apelacyjnego w Rzeszowie na sesji wyjazdowej w Dębicy, 19 XII 1950 r., k. 348-358. Sąd Najwyższy 5 V 1951 r. odrzucił rewizję, podtrzymując wyrok Sądu Apelacyjnego. 27 VII 1951 r. Bolesław Bierut, powołując się na prerogatywy prezydenta, zamienił karę śmierci na karę dożywotniego więzienia. 
niono opinią, że kobieta „za dużo wiedziała o organizacji «AK»”. Dodał, że zabójstwo zostało „zatwierdzone” przez podinspektora dębickiego obwodu AK Adama Lazarowicza ps. „Klamra”96.

W toku pracy konspiracyjnej „zakamuflowanej mundurem policyjnym” Wilhelm Jaki zwrócił się do komendanta dębickiego obwodu AK Ludwika Marszałka ps. „Zbroja” z prośbą o zezwolenie na zerwanie z policją i przejście do innej pracy podziemnej, „niewymagającej takiego napięcia nerwowego i intensywnej czujności”, ale Marszałek, jak zeznał: „kategorycznie mej prośbie odmówił z racji mojej możności przekazywania z mej strony informacji i dostępnych mi planach i zamierzeniach policji czy żandarmerii w stosunku do ludności polskiej i jej ruchu podziemnego oraz z racji możności przeprowadzenia z rozkazu władz akowskich akcji likwidacyjnej elementów szkodliwych narodowi i jego konspiracyjnej działalności" ${ }^{\prime 97}$.

Podobnie jak w wypadku większości samousprawiedliwień w kontekście postępowania karnego, niełatwo oddzielić prawdę od pretekstu lub wymuszonego zeznania. Narracja służąca przeniesieniu głównej odpowiedzialności na struktury podziemia budzi wiele wątpliwości. Biorąc pod uwagę, że postępowanie prowadzono na podstawie dekretu sierpniowego, trudno pominąc cele polityczne oskarżenia, które miał do wypełnienia Urząd Bezpieczeństwa. Starał się nadać rzeczywistości czasu wojny ramy pozwalające dokonać celnego ataku na najważniejsze postacie AK, które włączyły się w działalność antykomunistycznej organizacji Wolność i Niezawisłość. 1 marca 1951 r. Adam Lazarowicz został stracony w więzieniu mokotowskim. 27 listopada 1948 r. Ludwik Marszałek został stracony przez funkcjonariuszy wrocławskiego Urzędu Bezpieczeństwa Publicznego. Nie jest wykluczone, że Jaki postanowił obarczyć winą kierownictwo miejscowego podziemia, ułatwiając sobie zadanie przez wskazanie na zmarłego albo kogoś, kogo przynajmniej trudno było znaleźć. Nie mniej prawdopodobne jest wymuszenie zeznania przez UB w śledztwie, podyktowanego w taki sposób, by maksymalnie obarczało lokalne kierownictwo.

Teza, jakoby policjanci zabijali zbiegłych Żydów, aby zapobiec denuncjacji miejscowych mieszkańców, stanowi motyw przewodni uzasadnień przedstawianych przez oskarżonych polskich policjantów i winien być traktowany z dużą ostrożnością. Z jednej strony Armia Krajowa w podobwodzie wydawała swoim członkom wytyczne dotyczące „zachowania się wobec ukrywających się Żydów”, w których dowództwo zakazało „jakiegokolwiek kontaktu z uciekającymi Żydami i dawanie im pomocy”, uzasadnione rzekomym „sypaniem” osób okazujących uciekinierom pomoc ${ }^{98}$. Z punktu widzenia AK sprawy bezpieczeństwa

${ }^{96}$ Ibidem, Protokół przesłuchania podejrzanego Wilhelma Jakiego (kopia), Rzeszów, 5 IX 1950 r., k. 95.

${ }^{97}$ Ibidem, Prośba Wilhelma Jakiego do Ministerstwa Sprawiedliwości, k. 502-503.

${ }^{98}$ AIPN Rz, 105/7, Raporty Armii Krajowej, Rozkaz okresowy nr 3, punkt 21, Żuraw [płk Józef Maciołek, dowódca obwodu AK Rzeszów-Południe], 12 III 1943 r., k. 77. 


\section{Studia}

były szczególnie ważne, a wszystkich podejrzanych likwidowano bez zbędnych dociekań. Podobnie jak Jaki, wspomniany wcześniej komendant PP w Radomyślu Wielkim Jan Pielach twierdził, że miał zgodę miejscowych struktur Armii Krajowej na wykonywanie egzekucji w takich przypadkach. Z drugiej strony w czasie wojny zdarzało się, że miejscowa ludności istotnie bywała wystawiana na niebezpieczeństwo wydania przez ujętą osobę ${ }^{99}$. Inną sprawą jest sposób, w jaki realia okupacyjne mogły być wykorzystane na potrzeby strategii obronnej (stan wyższej konieczności) w kontekście powojennego postępowania sądowego, bez możliwości weryfikacji. Prawdziwość takich twierdzeń pozostaje uwikłana w koncepcję obrony oskarżonych.

Widać jednak, że osoby reprezentujące stanowisko graniczne, jakim była przynależność do Polnische Polizei i Armii Krajowej, stawały się tym bardziej szkodliwe dla uciekinierów żydowskich, jeśli w grę wchodziły też inne czynniki, takie jak gotowość lokalnego kierownictwa podziemia do przymykania oczu na zabijanie ludzi postrzeganych jako zagrożenie dla miejscowej ludności czy ze względu na wartość policjanta jako „wtyczki” w szeregach policji niemieckiej. W każdym razie udział Jakiego $\mathrm{w}$ działaniach antyżydowskich prawdopodobnie uwolnił go od podejrzeń ze strony policji niemieckiej. Wilhelm Jaki był jednym z wielu polskich policjantów, którzy brali udział w zabijaniu Żydów w okolicach Wielopola Skrzyńskiego ${ }^{100}$. Jego przypadek stanowi jeden koniec szerszego continuum, w którym życiu Polaka i Żyda nadawano różną wartość, co było elementem ewoluującej logiki przetrwania narodu pod okupacją. Wydaje się, że mający powiązania z podziemiem polscy policjanci, którzy mordowali zbiegłych Żydów traktowanych jako współodpowiedzialni za niemieckie represje przeciwko społecznościom lokalnym, interpretowali takie działania w kategoriach strat ubocznych.

\section{Ludność miejscowa}

Niezależnie od tego, co Niemcy uczynili, aby zmienić charakter i rolę policji granatowej jako formacji pomocniczej, i mimo stopniowego upadku moralnego jej funkcjonariuszy w latach okupacji pozostały w nich jeszcze niektóre elementy przedwojennego etosu, nakazującego im chronić ludność miejscową. Zarówno rząd RP na uchodźstwie, jak i podziemie wzywały powracających do służby policjantów, by stanowili bufor dla żyjącego pod okupacją społeczeństwa pol-

${ }^{99}$ Tomasz Frydel, Powiat dębicki [w:] Dalej jest noc. Losy Żydów w wybranych powiatach okupowanej Polski, t. 2, red. Barbara Engelking, Jan Grabowski, Warszawa: Stowarzyszenie Centrum Badań nad Zagładą Żydów, 2018, s. 456-464.

${ }^{100}$ Wśród żydowskich ofiar policjantów granatowych działających w tym regionie znajdowali się żona Nachmana Blumentala Maria i ich syn Ariel (Katrin Stoll, Traces of the Holocaust in Nachman Blumental's Archive. The Murder of Maria and Ariel Blumental in Wielopole Skrzyńskie during the German Occupation, „Yad Vashem Studies” 2021, t. 49, nr 2 (w przygotowaniu). 
skiego. Potencjał ten i związane z nim normy podlegały przekształceniom. Z jednej strony bowiem policjanci byli zmuszeni działać przeciwko swoim współobywatelom, m.in. przez odbieranie kontyngentów żywności i egzekwowanie pracy przymusowej, co często przybierało formę obław. Z drugiej strony opinia Polaków o policji granatowej była korzystniejsza na wsi, zwłaszcza w dystrykcie krakowskim - w przeciwieństwie do Warszawy ${ }^{101}$. Wraz z likwidacją państwa polskiego ludność została pozbawiona znacznej części ochrony prawnej przysługującej obywatelom. W miarę wydłużania się okupacji społeczeństwo polskie zaczęło się dostosowywać do status quo, a rola podziemia polegała na powstrzymywaniu dezintegracji społecznej oraz tego, co w tamtym czasie nazywano „demoralizacją”. Po usunięciu prawowitej polskiej władzy państwowej policja polska wchodziła niekiedy w próżnię powstałą po strukturach władzy w roli "rozwiązującego problemy” (problem solver) lub „obrońcy” społeczności lokalnych. Rolę tę można było odgrywać na rozmaite sposoby.

Ostrzeganie z wyprzedzeniem o obławach czy akcjach poszukiwawczych stanowiło kluczowy element sieci bezpieczeństwa, jaką policja granatowa mogła tworzyć w społecznościach lokalnych. Główną rolę pod tym względem odgrywali policjanci mający powiązania z podziemiem, ale nawet ci, którzy ewidentnie nie mieli takich kontaktów, często wcielali się w rolę obrońców danej społeczności. Edmund Czajka, w 1942 r. wcielony do „oddziału prowokacyjnego” złożonego z żandarmów i granatowych policjantów, którzy udawali partyzantów w okolicy Brzozowa (Kreis Krosno), symulował podczas wyprawy atak zapalenia wyrostka robaczkowego, co pozwoliło mu wrócić do domu i ostrzec mieszkańców ${ }^{102}$.

Gdy policjant Bronisław Stafin z posterunku w Szerzynach udawał chorego, w czym znalazł sposób na usunięcie go ze służby, w jego domu zjawiła się delegacja mieszkańców z prośbą o powrót do służby, ponieważ pod jego nieobecność „[w]zmógł się terror i prześladowanie Niemców, przed którym to terrorem Stafin ludność chronił” 103. Mieszkaniec wsi zeznał na rozprawie: „Prosiłem go [Stafina] by tego nie robił, bo ludność straci informatora” ${ }^{\prime 104}$. W rzeczy samej osiągnięcia Stafina w sferze łagodzenia skutków okupacji zasługują na uwagę. Dzięki uprzedzaniu mieszkańców w nocy po cywilnemu o niemieckich „ekspedycjach karnych", Stafin rzekomo uratował około 200 mieszkańców (w siedmiu

${ }^{101}$ Szymańska-Smolkin, „Fateful Decisions..., s. 90.

${ }^{102}$ AIPN Rz, 358/173, Protokół rozprawy głównej przed Sądem Wojewódzkim w Rzeszowie, Zeznanie Edmunda Czajki, 25 VII 1957 r., k. 166. W obawie, że Niemcy mogą podejrzewać, iż Czajka udaje chorego, przekonał lekarza w gorlickim szpitalu, aby go mimo wszystko operował. Więcej na temat podobnych działań prowokacyjnych zob. Dawid Golik, Prowokacja $w$ walce $z$ „,bandami”. Wybrane przykłady niemieckich akcji prowokacyjnych z terenu dystryktu krakowskiego GG, „Prace Historyczne” 2017, t. 144, z. 4, s. 691-711.

${ }^{103}$ AIPN Rz, 353/258, Pismo obrony do Sądu Apelacyjnego w Rzeszowie, 26 IX 1950 r., podsumowanie zeznania Józefa Kluzy, k. 140.

${ }^{104}$ Ibidem, Protokół rozprawy głównej przed Sądem Wojewódzkim w Rzeszowie na sesji wyjazdowej w Jaśle, Zeznanie Józefa Kluzy, 23 I 1951 r., k. 323. 


\section{Studia}

wioskach) wyznaczonych na wywiezienie do obozów i do pracy w Niemczech ${ }^{105}$. Sołtys Szerzyn wspominał o kilku przypadkach, kiedy to Stafin zorganizował pomoc dla biednych, chodząc po domach „ludzi zaufanych” i zbierając żywność, którą następnie w sposób dyskretny rozdawano biednym ${ }^{106}$.

Podobnie wójt i proboszcz w Szerzynach naciskali na policjanta Mikołaja Leszegę, cieszącego się przez osiem lat dobrą opinią, aby powrócił do służby dopomóc ludności w różnych trudnościach ${ }^{107}$. Policjant Stanisław Krasoń w Dębicy dostarczał miejscowej Radzie Głównej Opiekuńczej żywność i bony (Bezugsscheine) na chleb, które następnie RGO wysyłała więźniom w Pustkowie ${ }^{108}$. Z kolei lewicujący przedwojenny policjant z Żyrardowa, wspomniany wcześniej Marian Lenartowicz, który został przeniesiony do powiatu jasielskiego, wysyłał paczki żywnościowe dla znajomych Żydów żyrardowskich przebywających w getcie warszawskim oraz więźniom Auschwitz i osadzonym w getcie łódzkim ${ }^{109}$.

Rzeczywistość okupacji stworzyła świat, w którym przeciętny policjant stykał się z większą liczbą przypadków nieprzestrzegania niemieckich przepisów i uciekinierów, niż byłby w stanie ścigać. Czynniki sytuacyjne - takie jak obawa przed niemieckim zwierzchnikiem, oferta łapówki lub wcześniej istniejące stosunki - często odgrywały decydującą rolę w tym, czy i w jaki sposób „przestępstwo" było traktowane w ramach ograniczonej autonomii policjanta.

Szaja Altman relacjonował starcie się teściowej i szwagierki wraz z dziećmi z Policją Polską, kiedy zostali ujęci przez żandarmów w obławie w okolicy Połańca (Kreis Opatów, dystrykt radomski) pod koniec 1942 r. Żandarmeria dowiedziała się, że teściowa z córkami podobno są Żydówkami, aresztowano je i oddano na posterunek Policji Polskiej do przeprowadzenia śledztwa. „Komendant posterunku okazał się bardzo porządnym człowiekiem i kazał pod-

${ }^{105}$ Ibidem, Protokół rozprawy głównej, Zeznanie świadka ks. Jana Ślązaka, k. 321; ibidem, Pismo obrońcy, k. 139.

${ }^{106}$ Ibidem, Protokół rozprawy głównej, Zeznanie świadka Stanisława Gotfryda, 7 III 1951 r., k. 394.

${ }^{107}$ AIPN Rz, 354/73, Akta w sprawie karnej Mikołaja Leszegi, Protokół rozprawy głównej przed Sądem Okręgowym w Jaśle, Zeznanie ks. Jana Ślązaka, 29 VII 1948 r., k. 133-135; ibidem, Wyrok Sądu Okręgowego w Jaśle, 24 X 1949 r., k. 291. Ksiądz Ślązak dodał, że Leszega pozwolił trzyosobowej rodzinie żydowskiej Parizerów zbiec z aresztu - dał im gwóźdź, którym otworzyli zamek w drzwiach więzienia.

${ }^{108}$ AIPN Rz, 359/30, Akta w sprawie karnej Stanisława Krasonia, Protokół rozprawy głównej przed Sądem Wojewódzkim w Rzeszowie na sesji wyjazdowej w Dębicy, Zeznanie oskarżonego Stanisława Krasonia, 12 XI 1951 r., k. 9v; ibidem, Zeznanie świadka Włodzimierza Gardziela, byłego pracownika RGO, 13 XI 1951 r., k. 33v.

${ }^{109}$ AIPN Rz, 107/1783, t. 4, Protokół rozprawy głównej przed Sądem Powiatowym w Jaśle, Zeznanie Anieli Iżyckiej, siostry Lenartowicza, 15 VI 1949 r., k. 378-379; ibidem, Zeznanie Mariana Leczysłowskiego, byłego kierownika poczty w Brzostku, 15 VI 1949 r., k. 379-380. Leczysłowski zeznał, że Lenartowicz wysyłał dwie do trzech paczek tygodniowo, a czasem więcej. Paczki były przesyłane na adres ojca w Żyrardowie, potem ojciec i siostra je przepakowywali i ponownie nadawali na poczcie. 
dać [podać] takich świadków, którzy by stwierdzili, że są katoliczkami" - pisał Altman. Szwagierka przypomniała sobie znajomego Polaka z Mielca, ówcześnie policjanta w Dębicy, i na niego się powołała: „Komendant posterunku zadzwonił do niego, a on, słysząc głos, zaświadczył, że je zna i że są [to] katoliczki"110. Dzięki połączonym wysiłkom obu polskich policjantów matka z dziećmi została wypuszczona i wróciły do tej samej wsi, skąd je zabrano.

W innej części Podkarpacia Tema Herskowitz wspomniała o komendancie PP w Jarocinie w powiecie Nisko (Kreis Kraśnik, dystrykt lubelski) Władysławie Cieśli, znajomym sprzed wojny, który przyczynił się do uratowania życia „wielu Żydów”. Gdy jednak Herskowitz razem z matką i bratem Mordechajem Askienbergiem zostali ujęci przez kilkunastu miejscowych i doprowadzono ich na posterunek policji, Cieśla musiał działać w taki sposób, aby nie narażać własnego życia. Cieśla wraz z innym policjantem „zabrał nas do lasu, mówiąc ludziom $\mathrm{w}$ wiosce, iż prowadzą nas do gestapo w pobliskim mieście, gdzie ma się odbyć egzekucja. Następnie pozwolił nam odejść, ostrzegając, iż musimy być ostrożni i nie dać się złapać, ponieważ w przeciwnym razie również ich życiu grozić będzie niebezpieczeństwo. Była to prawda"111.

Decyzja o zerwaniu z narzuconymi przez władze niemieckie procedurami i udzielaniu pomocy uciekinierom wymagała oceny ryzyka przez rozważenie ewentualnych konsekwencji dla własnego życia. Żydzi, którzy mieli tzw. nieżydowski („dobry”) wygląd, zapewne znajdowali się na uprzywilejowanej pozycji pod względem zakresu udzielanej pomocy, ponieważ trudniej było ich rozpoznać jako Żydów, zatrzymać i zmusić do ujawnienia osób im pomagających. Prawdopodobnie z tego powodu wszyscy policjanci z niezidentyfikowanego posterunku w pobliżu Rzeszowa (Kreis Rzeszów) byli bardziej skłonni nie wykonać poleceń niemieckich, gdy miejscowy chłop przyprowadził na posterunek Zelmana Birenfelda: „Policja była polska. I dobry posterunkowy pytał mnie, czy chcę zginąć? Chciałem zginąć, bo myślałem, że rodzice nie żyją, i było mi już wszystko jedno. Na posterunku poradzili mi, bym poszedł na drugą wioskę, bo nie jestem podobny na Żyda. Pouczyli, jak się przeżegnać, jak się do roboty zabrać i wyprawili mnie w drogę, życie mi uratowali"112.

Znacznie większą śmiałością wykazał się krakowski policjant granatowy Stanisław Śliżewski, który w swoim domu ukrywał Zofię Korngold. Kiedy Korngold poprosiła policjanta, by wyciągnął z getta rzeszowskiego jej młodszego brata Zygmunta Żabnera, Śliżewski wybrał się do Rzeszowa, gdzie umówił się ze strażnikiem na portierni, że Żabner przyjdzie pod bramę getta i wyskoczy przez okno. Tak

${ }^{110}$ AŻIH, 301/2973, Relacja Szai Altmana, Wrocław, 17 X 1947 r., k. 10.

${ }^{111}$ Pismo Temy Herskowitz do Shmuela Krakowskiego, Brooklyn, 11 I 1984 r. [w:] Elżbieta Rączy, Pomoc Polaków dla ludności żydowskiej na Rzeszowszczyźnie 1939-1945, Rzeszów: IPN, 2008, s. 260.

${ }^{112}$ AŻIH, 301/2745, Relacja Zelmana Birenfelda, Chorzów, 26 VIII 1947 r., k. 2. 


\section{Studia}

się stało i policjant wrócił do Krakowa z bratem Korngold ${ }^{113}$. W innym przypadku podstawą do zaoferowania pomocy było zwykłe podobieństwo do kogoś z rodziny. W Kolbuszowej (Kreis Rzeszów) Norman Salsitz przypominał komendantowi policji Patkowi, przesiedlonemu z Wielkopolski w 1940 r., jego jedynego syna, który poległ w bitwie w 1939 r., co spowodowało, że zdecydował się pomóc młodemu człowiekowi. Patek poinformował Salsitza o planowanej likwidacji obozu pracy w Kolbuszowej, umożliwiając ucieczkę 55 Żydom nocą 18 listopada 1942 r. ${ }^{114}$

Zależnie od okoliczności posterunek policji mógł dla społeczności żydowskiej oznaczać śmierć (częściej) lub pomoc (rzadziej). Jakub Schenker relacjonował o przyjeździe gestapowców do Jodłowa (Kreis Jasło) w sierpniu $1942 \mathrm{r}$.: „Wydali jakieś rozporządzenia policji polskiej, która ostrzegła Żydów, że coś wisi w powietrzu. Tego dnia stu Żydów uciekło". Jednak w marcu 1943 r. policjanci $\mathrm{z}$ tego samego posterunku pojawili się w zupełnie innej roli: „brat mój wszedł do chaty chłopskiej, prosząc o jedzenie, wtedy chłopi skuli go łańcuchem i zaprowadzili na polską policję. Policjanci polscy zaprowadzili go do lasu i zastrzelili go. Równocześnie wykończyli Żydówkę z dwojgiem dzieci, ukrytych w lesie, których wydał jakiś Polak"115.

To właśnie w krytycznym kontekście obław na Żydów (Judenjagd) policjant granatowy w oczach społeczności wiejskiej często reprezentował postać, która potrafiła „rozwiązać” nagły problem powstały w warunkach okupacji. W przeciwieństwie do policji niemieckiej, która najprawdopodobniej zareagowałaby gwałtowną i trudną do przewidzenia przemocą, Policja Polska nieraz działała w sposób bardziej przewidywalny i z większym umiarem. Kiedy Ita Weissmann znalazła chwilowe schronienie u rodziny Kowalskich w Borku w pobliżu Mielca (Kreis Dębica), znienacka zjawiła się policja granatowa, by zabrać Kowalskiego na roboty do Niemiec. W czasie rewizji policjant Zdzisław Sarnowski wykrył Weissmannową, lecz presja rodziny Kowalskich wywarta na Sarnowskiego zapobiegła jej aresztowaniu: „Uratowała mnie tylko zdecydowana postawa całej rodziny, która apelując do sumienia Sarnowskiego, jego polskości, przedwojennej jeszcze znajomości z rodziną, wypchnęła go z domu"116. Częściej jednak zbiorowa presja wypychała Żydów z kryjówek w bezpośrednie zagrożenie życia.

Bardziej reprezentatywny dylemat zachodził wówczas, gdy mieszkańcy wsi postrzegali wybór między własnym przetrwaniem a przetrwaniem uciekinie-

${ }^{113}$ Archiwum Yad Vashem, M.31, Department for the Righteous among the Nations, 7399, Teczka Stanisława Śliżewskiego, Relacja Adolfa Żabnera, 4 XII 1995 r., b.p.; ibidem, Relacja Zygmunta Krausa, 20 XI 2006 r., b.p. Kraus dodał, że wywołano w getcie pożar, co spowodowało nieuwagę ze strony Niemców i pozwoliło Żabnerowi wyskoczyć przez okno.

${ }^{114}$ Norman Salsitz, Amalie P. Salsitz, Against All Odds: A Tale of Two Survivors, New York: Holocaust Library, 1990, s. 253-255; Norman Salsitz, Stanley Kaish, Three Homelands: Memories of a Jewish Life in Poland, Israel, and America, Syracuse: Harvard University Press, 2002, s. 133.

${ }^{115}$ AŻIH, 301/1694, Relacja Jakuba Schenkera, Kraków, b.d., k. 1.

${ }^{116}$ Prywatne archiwum Stanisława Wanatowicza w Mielcu, Wspomnienia Ireny (Ity) Buś-Weissmann, b.d., s. 3; kopia w zbiorach autora. 
rów Żydów - to właśnie w tym w świetle widzieli rolę policjantów granatowych. Kiedy zatem mieszany patrol złożony z dwóch żandarmów i polskiego policjanta Stanisława Kozioła z Gawłuszowic (Kreis Dębica) pojawił się w domu Józefa Mądrego w Chorzelowie w wyniku uzyskania informacji, że gospodarz kogoś ukrywa, postawili wybór w charakterystyczny sposób: „Szukano wszędzie, w każdym budynku i zakątku, a kiedy nic nie znaleziono, ów granatowy policjant odwołał mnie na bok i powiada: wiem, że kogoś przechowujesz, jeżeli to Polak, to nic, ale jeżeli bolszewik lub Żyd, to skiń głową, gdzie jest, nie musisz nawet mówić, wyprowadzimy za stodołę, kropniemy, i ty będziesz miał spokój, i my"117. Ponieważ Mądry nie chciał wydać dwóch kobiet - Sary Kanarek i jej córki Miriam - które wraz z żoną ukrywał w kryjówce używanej wcześniej przez polskiego żołnierza, nakazano mu zgłosić się do północy na posterunek Kripo w Mielcu. Mądry opuścił dom, sądząc, że już nie wróci, ale uratowała go interwencja członka Batalionów Chłopskich ${ }^{118}$. Bardziej typową reakcją w obliczu tego dylematu było jednak podjęcie przez obie strony proponowanej przez policję granatową propozycji „pokojowej”.

Dwoistość policjantów wobec uciekinierów żydowskich była funkcją zmieniających się warunków. W innych okolicznościach wspomniany poprzednio policjant Kozioł, będąc w domu Julii Gnidy we wsi Kliszów, zobaczył na strychu stajni ukrywającego się Mozesa Horna, „ale nic nie mówił, tak jakby o nim nie wiedział i nie zrobił z tego żadnego użytku", a później ostrzegł ją o zbliżającej się łapance, „żeby owego Żyda ukryć”, co pomogło Hornowi dożyć wyzwolenia ${ }^{119}$. Uosobienie tej dwoistości występującej wśród niektórych policjantów można by nazwać „sprawcą-ratującym” (perpetrator-rescuer), gdyż na różne sposoby zarazem pomagali Żydom, jak i ich krzywdzili. Jako przykład można przywołać postać Michała Strzępki, policjanta z Radomyśla Wielkiego (Kreis Dębica) i członka Armii Krajowej, który za okupacji zastrzelił kilkunastu Żydów, choć na jego procesie ujawniono, że od 1940 r. wraz z żoną i córką ukrywał rodzinę Berlów zbiegłą z Krakowa, umieszczając ich u poszczególnych gospodarzy w okolicznych wioskach i pomagając w uzyskaniu produktów żywnościowych. Dzięki skoordynowanej pomocy rodziny policjanta Berlowie dożyli końca wojny ${ }^{120}$. Co ciekawe, dwoistość policjanta nie była znana ukrywającym się ${ }^{121}$.

${ }^{117}$ Ibidem, Wspomnienia Józefa Mądrego, Chorzelów, 1980 r., s. 5; kopia w zbiorach autora.

${ }^{118}$ Ibidem, k. 5; Prywatne archiwum Stanisława Wanatowicza w Mielcu, Wspomnienia Miriam Cooper (z domu Kanarek), czerwiec 1989 r., s. 4; kopia w zbiorach autora.

${ }^{119}$ AIPN Rz, 353/256, Akta w sprawie karnej Stanisława Kozioła, Protokół przesłuchania świadka Julii Gnidy, Mielec, 10 XI 1950 r., k. 316-317. Fakt, że z Kliszowa nikt nie został wywieziony do Niemiec, Gnida przypisuje ostrzeżeniom Kozioła, żeby ludzie się chowali.

${ }^{120}$ AIPN Rz, 34/64, t. 1, Akta dochodzenia śledztwa Michała Strzępki, Protokół przesłuchania świadka Wiktorii Wolińskiej (z domu Berl), Tarnów, 25 V 1965 r., k. 183-187.

${ }^{121}$ Ibidem, k. 187: „W czasie pobytu mojego na terenie Radomyśla Wielkiego i okolicznych wsiach nigdy nie słyszałam ani nie widziałam, aby Strzępka jako policjant prześladował ukrywających się Żydów. Po moim wyjeździe z terenu Radomyśla [sierpień 1942 r.] nigdy nie sły- 
Trudno jednak znaleźć bardziej skrajne uosobienie zjawiska „sprawcy-ratującego” na Podkarpaciu niż Karol Stachak ps. „Róża”, komendant Policji Polskiej w Czudcu (Kreis Rzeszów), a zarazem dowódca AK w tej miejscowości ${ }^{122}$. Z jednej strony Stachak był cenionym członkiem Armii Krajowej wykonującym na donosicielach, bandytach i innych ludziach uznanych za niebezpiecznych dla organizacji i miejscowej ludności wyroki śmierci - a wszystko to pod osłoną pracy w policji. Szukający schronienia Żydzi uważali go również za niezawodnego pomagającego - sam przez kilka miesięcy ukrywał w swoim domu żydowskiego chłopca Wilnera, w czasie kiedy inni bali się go przyjąć, i odwracał wzrok, gdy miejscowi ukrywali Żydów lub jeńców radzieckich ${ }^{123}$. Z drugiej strony wiosną $1943 \mathrm{r}$. miejscowi przyprowadzili na posterunek policji w Lubenii, gdzie w owym czasie Stachak służył jako komendant, Żyda imieniem Szymon. Stachak zatelefonował na posterunek żandarmerii w Czudcu i dostał polecenie wykonania egzekucji. Decyzja ta została później zmieniona, a policjanci mieli eskortować zatrzymanego do Czudca. W trakcie przesłuchania Szymon rzekomo ujawnił tożsamość ośmiu rodzin, które udzieliły mu schronienia. Przekonany, że przekazanie go żandarmerii przyniesie śmierć owym rodzinom, Stachak oraz policjant Jacek Szulga podjęli decyzję zastrzelenia Szymona za posterunkiem policji ${ }^{124}$.

Sprawa Stachaka - który za swoją działalność podziemną został odznaczony Orderem Virtuti Militari V klasy - podważyła prawne i polityczne znaczenie kolaboracji wprowadzone w dekrecie sierpniowym, a oparte na określeniu „idąc na rękę” władzom państwa niemieckiego. Warto tu odtworzyć charakterystykę policjanta sformułowaną przez sąd: „Postępowaniem swoim w całym

szałam, aby Strzępka brał udział w ujęciu lub rozstrzeliwaniu Żydów". Ukrywając się w okolicy Krakowa, Wolińska pozostawała w listownym kontakcie ze Strzępką do 1944 r.

${ }^{122}$ Stachak był przedwojennym policjantem, który służył w Czudcu od 1933 r. i wrócił do służby na ten sam posterunek w listopadzie 1939 r. W 1941 r. został przeniesiony na nowo utworzony posterunek w Lubenii, gdzie służył do chwili likwidacji posterunku pod koniec 1942 r., a następnie powrócił do Czudca jako plutonowy. Służył w Czudcu do września 1943 r., po czym został przeniesiony na stanowisko komendanta straży młyńskiej w Wyżnie, które zajmował do maja 1944 r. Stachak został zaprzysiężony przez ZWZ w 1940 r. Jestem wdzięczny Piotrowi Szopie, który pierwszy zwrócił moją uwagę na tę sprawę. Więcej o złożonej biografii działalności Stachaka zob. Szopa, Funkcjonariusze Policji Polskiej..., s. 88-96.

${ }^{123}$ AIPN Rz, 353/18, Akta w sprawie karnej Karola Stachaka, Protokół przesłuchania świadka Edwarda Brydka, Rzeszów, 28 VII 1948 r., k. 111-112; ibidem, Protokół rozprawy głównej przed Sądem Okręgowym w Rzeszowie, Zeznanie świadka Chaskiela Wiesenfelda, 5 VIII 1948 r., k. 235-236. Wilner podobno dożył wyzwolenia i po wojnie zamieszkał w Australii.

${ }^{124} 8 \mathrm{~V} 1944$ r. Gestapo aresztowało Stachaka za powiązania z Armią Krajową, osadzono go w Rzeszowie, gdzie, torturowany, próbował popełnić samobójstwo, aby nie ujawnić poufnych informacji o podziemiu. Stachak rozciął sobie żołądek nożem. Świadome, że ma do czynienia z ważnym członkiem konspiracji, Gestapo postanowiło uratować mu życie, przenosząc go do szpitala w Tarnowie, z którego Stachak, korzystając z pomocy podziemia, zdołał zbiec 27 VII $1944 \mathrm{r}$. 
tym okresie [Stachak] dowiódł, że jest człowiekiem o charakterze chwiejnym, niezdecydowanym, o nieustalonych przekonaniach politycznych, człowiekiem o podwójnym obliczu. Jest członkiem AK, a okazuje przy tym sympatię ludziom o przekonaniach komunistycznych, żydom. Świadczy ludziom wiele dobrego, pomaga im w różnych sytuacjach, niekiedy z narażaniem siebie samego, równocześnie zaś zapominając o tym, że jest posterunkowym policji granatowej, pod kontrolą władzy niemieckiej, umiejętnie robi użytek z powierzonej mu broni palnej i swoją gorliwością wyróżnia się spośród innych posterunkowych, zawsze jest tym, którego niemcy mogą być pewni, gdy chodzi o tępienie ludzkich istnień"125. Mimo niejednoznacznej roli, jaką odegrał Stachak, sąd skazał go na śmierć ${ }^{126}$.

Historyk Piotr Szopa odnotowuje, że losy tego policjanta stanowią ,jak gdyby szablon", w jaki wpisywało się wielu funkcjonariuszy, balansowania na cienkiej linii „między przymusowym wykonywaniem zarządzeń okupanta a współpracą z nim"127. W istocie sprawa Stachaka jest symbolem szerszego paradoksu wiążącego się z wieloma funkcjonariuszami policji granatowej: „sprawców-ratujących" czy „ludzi o podwójnym obliczu”, kiedy górę brała arytmetyka przetrwania społeczności pod okupacją. W wielu przypadkach stanowisko podziemia wzmacniało zbiorowy instynkt samozachowawczy. $\mathrm{W}$ obliczu pytania, jakie działania powinien podjąć jako granatowy policjant i członek AK wobec ukrywających się Żydów, Brunon Mrowiński zwrócił się jakoby do miejscowego dowódcy i księdza, ci zaś doradzili mu, „aby w poszczególnych gromadach, gdzie mieli ukrywać się Żydzi, zrobił zebranie z mieszkańcami gromad celem uprzedzenia ich, aby nie przechowywali Żydów, a jeśli kto przechowuje, to aby tych Żydów odpędził od siebie, gdyż inaczej będą przeprowadzane rewizje"128. Miejscowi przypomnieli sobie te spotkania, na których zachęcano ich do denuncjowania Żydów, aby w ten sposób uniknąć podpalenia domu, co niedługo wcześniej zdarzyło się w sąsiedniej wiosce.

W podobny sposób policjant Edmund Czajka usprawiedliwiał przed sądem - a być może i przed samym sobą - rozstrzelanie sowieckiego partyzanta jako „dobry uczynek”, twierdząc, iż zastrzelił go z obawy, że zadenuncjuje do władz niemieckich większość ludzi, którzy udzielili mu schronienia. $\mathrm{W}$ jego przekona-

${ }^{125}$ AIPN Rz, 353/19, Akta w sprawi karnej Karola Stachaka, Sentencja wyroku Sądu Okręgowego w Rzeszowie, 12 III 1949 r., k. 117-123. Sąd uznał go za winnego śmierci pięciu osób.

${ }^{126}$ Na kolejnej rozprawie Sąd Apelacyjny w Rzeszowie 24 X 1949 r. uznał Stachaka za winnego śmierci czterech osób, skazując go na śmierć za popełnienie wszystkich czterech czynów. Sąd Najwyższy odrzucił rewizję, podtrzymując wyrok Sądu Apelacyjnego. W 1950 r., stosując akt łaski, prezydent Bolesław Bierut zamienił karę śmierci na karę dożywotniego więzienia, a w 1954 r. Sąd Najwyższy zmniejszył wyrok do 15 lat więzienia.

${ }^{127}$ Szopa, Funkcjonariusze Policji Polskiej..., s. 96.

${ }^{128}$ AIPN Rz, 052/239, Akta śledztwa w sprawie Brunona Mrowińskiego, Protokół przesłuchania oskarżonego Mrowińskiego, Mielec, 21 VI 1954 r., k. 39-40. 


\section{Studia}

niu ocalił w ten sposób co najmniej 15 osób od wywózki do Auschwitz ${ }^{129}$. Prawdą jest, że w strategiach obronnych przed sądem starano się usprawiedliwiać zabijanie zarówno zbiegłych Żydów, jak i sowieckich jeńców wojennych, chęcią zapobieżenia dalszym represjom ze strony Niemców wymierzonym w mieszkańców, nadając tym argumentom walor „patriotyzmu”. Podczas wojny po tego rodzaju logikę sięgano w następstwie surowych represji wobec miejscowej ludności za ukrywanie Żydów. To właśnie w takich momentach kryzysu egzystencjalnego w danej wspólnocie i pod wpływem paniki ludność odwoływała się do policji granatowej, traktując ją jako pierwszych i najbliższych pośredników i obrońców. Najbardziej dramatyczny dający się zrekonstruować przypadek na Podkarpaciu, gdy Policja Polska stała się „gorliwym katem” działającym w imieniu wspólnoty, wydarzył się w trakcie tzw. działań pacyfikacyjnych 23 kwietnia 1943 r. w miejscowości Podborze, gdzie przez dwa tygodnie zatrzymano i zabito ponad 30 Żydów; głównymi sprawcami byli polscy policjanci z dwóch posterunków ${ }^{130}$. Właśnie w tak toksycznej atmosferze strachu i chęci ocalenia własnego życia przemoc uległa zbiorowej „prywatyzacji”131, w której ramach policjanci - potencjalnie - mogli funkcjonować w danej społeczności jako swego rodzaju pluton egzekucyjny ${ }^{132}$.

\section{Wnioski}

Badacz ludobójstwa Donald Bloxham napisał, że „zrozumienie sprawcy i sprawstwa jest zasadniczym warunkiem zrozumienia ludobójstwa”, a wszystkie inne punkty widzenia mają jedynie znaczenie pomocnicze ${ }^{133}$. Jeśli chodzi o policję granatową wobec Zagłady, perspektywa „sprawcy” przez dziesiątki lat PRL leżała odłogiem, wraz z powojennymi zapisami procesowymi, które umożliwiłyby taką rekonstrukcję. Jedną z głównych konsekwencji opóźnionej dyskusji na temat „kolaboracji” na ziemiach polskich jest to, że typologia sprawców w kontekście polskim pozostaje w znaczącym stopniu niedostatecznie opracowana przez historyków, a badania publikowane w ostatniej dekadzie w dużej mierze nie są zintegrowane z szerszą dziedziną badań nad sprawcami Zagłady.

${ }^{129}$ AIPN Rz, 358/173, Protokół przesłuchania oskarżonego Edmunda Czajki, 26 IV 1956 r., k. 10.

${ }^{130}$ Tomasz Frydel, The Pazifizierungsaktion as a Catalyst of Anti-Jewish Violence. A Study in the Social Dynamics of Fear [w:] The Holocaust and European Societies: Social Processes and Dynamics, red. Frank Bajohr, Andrea Löw, London: Palgrave Macmillan, 2016, s. 147-166.

131 Timothy Snyder, Czarna ziemia. Holokaust jako ostrzeżenie, tłum. Bartłomiej Pietrzyk, Kraków: Znak, 2015, s. 272.

132 „Nadmieniam, że mieszkańcy chcieli dokonać samorządu [samosądu] nad Żydami, jednak ja do tego nie dopuściłem", zeznał były komendant PP w Radomyślu Wielkim Jan Pielach (AIPN Rz, 32/1, Protokół rozprawy głównej, Zeznanie oskarżonego Pielacha, k. 96).

${ }^{133}$ Donald Bloxham, From Streicher to Sawoniuk: The Holocaust in the Courtroom [w:] The Historiography of the Holocaust, red. Dan Stone, Basingstoke: Palgrave Macmillan, 2004, s. 414. 
W artykule podjąłem się przeanalizowania udziału policji granatowej w Zagładzie w świetle trójelementowej matrycy nacisków, która miała decydujące znaczenie dla kształtowania działań jej funkcjonariuszy w szerszym kontekście okupacji. Zbadane tutaj potężne siły kontekstowe pozwalają uwypuklić rolę czynników sytuacyjnych w przeciwieństwie do czynników charakterologicznych i ideologicznych. Wydaje się, że zjawisko zabijania Żydów przez policjantów podlegało zmianom w zależności od czasu i miejsca. Brutalizacja, do jakiej doszło w następstwie prowadzonych przez Niemców w okresie 1942-1943 większych operacji o charakterze mordów, przyczyniła się do degradacji wartości społecznych wśród lokalnej policji i ludności. Nie ulega wątpliwości, że policjanci odziedziczyli przedwojenne antysemickie klisze i stereotypy. To z pewnością ułatwiało im negatywne nastawienie do Żydów przy odmiennym do obywateli polskich. Jednak tak szeroko rozumiany antysemityzm kulturowy wskazywałby na dość słaby związek między myśleniem a działaniem w odniesieniu do zabijania. Rozpoznanie tej kwestii ogranicza charakter powojennych dochodzeń i procesów, gdyż problem antysemityzmu pozostaje w nich w dużej mierze przemilczany. Tylko poszerzona perspektywa chronologiczna, obejmująca lata międzywojenne, pozwoli lepiej naświetlić ciągłości ideologiczne i instytucjonalne.

Ogólnie rzecz biorąc, obraz funkcjonariuszy Policji Polskiej, jaki się tu wyłania, to obraz ludzi bardziej „zwykłych” niż członkowie Policji Porządkowej. Historyk Timothy Snyder wykorzystuje policję granatową jako studium przypadku pozwalające zobrazować, co się dzieje, gdy instytucja państwowa jest oddzielona od państwa zniszczonego od środka ${ }^{134}$. Postępowanie takich kolaborantów wymaga raczej mniej wyjaśnień niż działania policji niemieckiej, ponieważ nie mieli oni żadnych praw, na które jako obywatele mogliby się zdać. Zapewne nie jest przypadkiem, że policjanci często podkreślali, iż zasady polskiego państwa ich nie dotyczą, nawet gdy tego rodzaju samousprawiedliwienie w latach 1943-1944, gdy stało się oczywiste, że Niemcy przegrają wojnę, było właściwie pustosłowiem. Jeszcze bardziej istotne jest, by powiedzieć o policjantach granatowych to, co Mark Roseman powiedział o niemieckich policjantach i szeregowych żołnierzach - że nie byli oni „W żadnym sensie kowalami własnego losu” 135 . To przede wszystkim Polnische Polizei była „zwykłą organizacją”136, oderwaną od przedwojennego państwa polskiego i wprzęgniętą w nazistowską maszynerię zagłady, co miało decydujący wpływ na zbrodnicze działania jej funkcjonariuszy. Jeśli zniknie nam $\mathrm{z}$ oczu to istotne spostrzeżenie, ryzykujemy popełnieniem błędu kategorialnego i „inflacją sprawczości” (agency inflation), przed czym ostrzegał Timothy Snyder

${ }^{134}$ Snyder, Czarna ziemia..., s. 87-89.

${ }^{135}$ Mark Roseman, The Lives of Others - Amid the Deaths of Others: Biographical Approaches to Nazi Perpetrators, „Journal of Genocide Research” 2013, t. 15, nr 4, s. 446.

${ }^{136}$ Stefan Kühl, Ordinary Organisations: Why Normal Men Carried Out the Holocaust, Cambridge: Polity Press, 2016. 


\section{Studia}

w odniesieniu do pisania mikrohistorii Zagłady ${ }^{137}$. Jest to tym bardziej istotne, że dla członków polskiego podziemia służących w policji granatowej, zabijanie Żydów (i Polaków) nie pokrywało się z żadnym klarownym programem politycznym, przewidującym utworzenie etnicznie jednorodnej przestrzeni geopolitycznej, jak było w wypadku członków OUN wstępujących do ukraińskiej policji na zachodnich obszarach Ukrainy ${ }^{138}$. Jednocześnie, jak starałem się pokazać w tekście, członkowie policji granatowej nie byli po prostu sumiennymi funkcjonariuszami, którzy wykonywali rozkazy, nawet jeśli w ten sposób próbowali usprawiedliwić swoje działania. Wszelako, biorąc pod uwagę złożony zbiór relacji, które stanowiły ramę dla ich działań, znaleźli się w sytuacji znacznie bardziej d y n a m i c z n e j.

Empatia historyczna jako kluczowe narzędzie hermeneutyczne do zrozumienia przeszłości niezbyt pasuje do badań nad sprawcami Zagłady. Mark Roseman wskazał na „niedopuszczalność empatii” w bieżących niemieckich badaniach nad sprawcami i na to, jak takie „ograniczenie moralne” powoduje, że ostatecznie sprawca pozostaje „nieprzenikniony” ${ }^{39}$. Sądzę, że analogiczne spostrzeżenie należy odnieść do policjantów granatowych - postrzeganie ich w redukcyjnych i wzajemnie wykluczających się kategoriach bohaterów, sprawców, ratujących, kolaborantów czy przepełnionych nienawiścią antysemitów umieszcza funkcjonariuszy Polnische Polizei wśród istot nieprzeniknionych. Aby odejść od takiego esencjonalistycznego myślenia o policji granatowej, należy zacząć zauważać liczne odcienie szarości.

\section{Z języka angielskiego przełożył Jerzy Giebułtowski}

\section{BIBLIOGRAFIA}

\section{Źródła archiwalne}

\section{Archiwum Akt Nowych}

203/III-117, Armia Krajowa

203/VIII-2, Komenda Główna AK, Kierownictwo Walki Podziemnej

231/II-2, Dzienniki, kroniki, pamiętniki

Archiwum Instytutu Pamięci Narodowej Oddział w Krakowie

502/101, Akta Specjalnego Sądu Karnego w Krakowie w sprawie karnej przeciwko Władysławowi Rzepie

Archiwum Instytutu Pamięci Narodowej Oddział w Rzeszowie

042/2126, Dochodzenie operacyjne w sprawie Kajetana Paprowskiego

052/239, Akta śledztwa w sprawie Brunona Mrowińskiego

${ }^{137}$ Timothy Snyder, Collaboration in the Bloodlands, odpowiedź na recenzje Johna Connelly'ego, Marka Rosemana, Andriya Portnova i Michaela David-Foxa, zebrane jako: Bloodlands: Europe between Hitler and Stalin by Timothy Snyder, „Journal of Genocide Research” 2011, t. 13, nr 3, s. 347-349, tu 348.

${ }^{138}$ Yuri Radchenko, We Emptied Our Magazines into Them. The Ukrainian Auxiliary Police and the Holocaust in Generalbezirk Charkow, 1941-1943, „Yad Vashem Studies” 2013, t. 41, nr 1, s. 88, 98.

${ }^{139}$ Roseman, The Lives of Others..., s. 457. 
$055 / 24$, Wykazy byłych funkcjonariuszy policji granatowej w powiecie mieleckim 32/1, Akta w sprawie karnej Jana Pielacha

34/64, t. 1, Akta dochodzenia śledztwa Michała Strzępki

105/7, Raporty Armii Krajowej, Rozkaz okresowy nr 3

$107 / 1783$, Akta w sprawie karnej Władysława Malawskiego, Mariana Lenartowi-

cza i Huberta Kuczery

352/2, Akta w sprawie karnej przeciwko Mieczysławowi Ożdze

352/177, Akta Specjalnego Sądu Karnego w Rzeszowie w sprawie karnej przeciwko Adamowi Ptaszkowi

353/18-19, Akta w sprawie Karola Stachaka

353/31, Akta w sprawie karnej Izabeli Kędzierskiej

353/110, Akta w sprawie Piotra Zemły

353/243, Akta w sprawie karnej Ludwika Ostrowskiego

353/256, Akta w sprawie Stanisława Kozioła

353/258, Akta w sprawie karnej Bronisława Stafina

353/278, Akta w sprawie karnej Wilhelma Jakiego

354/9, Akta w sprawie Wincentego Wontorowskiego (Wątorowskiego)

354/73, Akta w sprawie Mikołaja Leszegi

358/5, Akta w sprawie Władysława Malawskiego, Józefa Barana i Antoniego Tumidajewicza

358/170, Akta w sprawie karnej Jana Krupy

358/173, Akta w sprawie karnej Edmunda Czajki

359/15, Akta w sprawie Antoniego Sroczyńskiego

359/30, Akta w sprawie karnej Stanisława Krasonia

Okręgowa Komisja Ścigania Zbrodni przeciwko Narodowi Polskiemu w Rzeszowie, S 2/00/Zn, Dochodzenie w sprawie zbrodni popełnionych w Pustkowie

Archiwum Państwowe w Radomiu

W-741, Akta Więzienia Radomskiego

Archiwum Państwowe w Rzeszowie zespół 26, sygn. 209, Sąd Specjalny w Rzeszowie (Sondergericht Reichshof)

Archiwum Yad Vashem

M.31, Department for the Righteous among the Nations, 7399, Teczka Stanisława Śliżewskiego

Archiwum Żydowskiego Instytutu Historycznego

301/1649, Relacja Abrahama Pellera

301/1694, Relacja Jakuba Schenkera

301/2745, Relacja Zelmana Birenfelda

301/2973, Relacja Szai Altmana

Bundesarchiv, Aussenstelle Ludwigsburg

B 162/7478, Akta śledcze w sprawie Drosdza, Hesslera i innych

Centralne Archiwum Wojskowe Wojskowego Biura Historycznego

II.33.44, Bataliony Chłopskie, Obwód IV

Prywatne archiwum Stanisława Wanatowicza w Mielcu

Wspomnienia Ireny (Ity) Buś-Weissmann

Wspomnienia Miriam Cooper (z domu Kanarek)

Wspomnienia Józefa Mądrego

USC Shoah Foundation, Visual History Archive

48515, Wywiad z Antonim Balarynem 


\section{Źródła publikowane}

Nakazy chwili, „Biuletyn Informacyjny Małopolski”, 13 VIII 1942, nr 23.

„Verordnungsblatt des Generalgouverneurs für die besetzeten polnischen Gebiete” (Dziennik Rozporządzeń Generalnego Gubernatora dla Okupowanych Polskich Obszarów), 2 XI 1939, nr 2.

\section{Literatura przedmiotu i inne publikacje}

Bloxham Donald, From Streicher to Sawoniuk: The Holocaust in the Courtroom [w:] The Historiography of the Holocaust, red. Dan Stone, Basingstoke: Palgrave Macmillan, 2004.

Bolianovskyi Andrii, Młynarczyk Jacek Andrzej, Rein Leonid, Romanko Oleg, Belarusian Auxiliaries, Ukrainian Waffen-SS Soldiers and the Special Case of the Polish 'Blue Police' [w:] The Waffen-SS: A European History, red. Jochen Böhler, Robert Gerwarth, Oxford: Oxford University Press, 2017.

Browning Christopher R., Nazi Policy, Jewish Labor, German Killers, Cambridge: Cambridge University Press, 2000.

Browning Christopher R., Zwykli ludzie. 101. Rezerwowy Batalion Policji i „ostateczne rozwiązanie” $w$ Polsce, tłum. Piotr Budkiewicz, wyd. 2 popr. i uzup., Poznań: Rebis, 2019.

Dąmbski Stefan, Egzekutor, Warszawa: Ośrodek Karta, 2010.

Dworzecki Jacek, Policja w Polsce we wrześniu 1939 roku, „Zeszyt Naukowy [Wyższej Szkoły Bezpieczeństwa Publicznego i Indywidualnego Apeiron w Krakowie]” 2010.

Finder Gabriel N., Prusin Alexander V., Justice behind the Iron Curtain: Nazis on Trial in Communist Poland, Toronto: University of Toronto Press, 2018.

Frydel Tomasz, Ordinary Men? The Polish Police and the Holocaust in the Subcarpathian Region [w:] Mittäterschaft in Osteuropa im Zweiten Weltkrieg und im Holocaust / Collaboration in Eastern Europe during World War II and the Holocaust, red. Peter Black, Béla Rásky, Marianne Windsperger, Wien/Vienna: New Academic Press, 2019.

Frydel Tomasz, The Pazifizierungsaktion as a Catalyst of Anti-Jewish Violence. A Study in the Social Dynamics of Fear [w:] The Holocaust and European Societies: Social Processes and Dynamics, red. Frank Bajohr, Andrea Löw, London: Palgrave Macmillan, 2016.

Frydel Tomasz, Powiat dębicki [w:] Dalej jest noc. Losy Żydów w wybranych powiatach okupowanej Polski, t. 2, red. Barbara Engelking, Jan Grabowski, Warszawa: Stowarzyszenie Centrum Badań nad Zagładą Żydów, 2018.

Geertz Clifford, Thick Description: Toward an Interpretive Theory of Culture [w:] The Interpretation of Cultures: Selected Essays, New York: Basic Books, 1973 [wyd. polskie: Interpretacja kultur. Wybrane eseje, tłum. Maria M. Piechaczek-Borkowska, Kraków: Wydawnictwo UJ, 2005].

Getter Marek, Policja Polska w Generalnym Gubernatorstwie 1939-1945, „Przegląd Policyjny" 1999 , t. 9, nr 1/2.

Gieroń Roman, Półmrok. Procesy karne w sprawie przestępstw okupacyjnych popełnianych przez chłopów wobec Żydów w województwie krakowskim, Kraków: IPN, 2020.

Goldhagen Daniel Jonah, Gorliwi kaci Hitlera. Zwyczajni Niemcy i Holokaust, tłum. Wiesław Horabik, Warszawa: Prószyński i S-ka, 1999.

Golik Dawid, Prowokacja $w$ walce $z$ "bandami”. Wybrane przykłady niemieckich akcji prowokacyjnych z terenu dystryktu krakowskiego GG, „Prace Historyczne” 2017, t. 144 , z. 4. 
Grabowski Jan, Na posterunku. Udział policji granatowej i kryminalnej w zagładzie Żydów, Wołowiec: Czarne, 2020.

Hempel Adam, Pogrobowcy klęski: Rzecz o policji „granatowej” w Generalnym Gubernatorstwie 1939-1945, Warszawa: PWN, 1990.

Kalisz Michał, Józef Laska - policjant i żołnierz konspiracji, „Rocznik Sądecki” 2011, t. 39.

Kalisz Michał, Rączy Elżbieta, Dzieje społeczności żydowskiej powiatu gorlickiego podczas okupacji niemieckiej 1939-1945, Rzeszów: IPN, 2015.

Kania Marcin, Losy funkcjonariuszy policji II Rzeczypospolitej Polskiej w Polsce Ludowej, „Pamięć i Sprawiedliwość” 2012, nr 1.

Korkuć Maciej, Niemiecka Polnische Polizei. Historyczny i państwowo-prawny kontekst funkcjonowania granatowej policji w Generalnym Gubernatorstwie 1939-1945 [w:] Policja granatowa w Generalnym Gubernatorstwie w latach 1939-1945, red. Edyta Majcher-Ociesa, Tomasz Domański, Kielce: IPN, 2019.

Kornbluth Andrew, The August Trials: The Holocaust and Postwar Justice in Poland, Cambridge, MA: Harvard University Press, 2021.

Krempa Andrzej, Zagłada Żydów mieleckich, Mielec: Muzeum Regionalne w Mielcu, 2013.

Kühl Stefan, Ordinary Organisations: Why Normal Men Carried Out the Holocaust, Cambridge: Polity Press, 2016.

Libionka Dariusz, Zagłada Żydów w Generalnym Gubernatorstwie. Zarys problematyki, Lublin: Państwowe Muzeum na Majdanku, 2017.

Lista ostaszkowska. Studia i materiały, red. Andrzej Misiuk, Szczytno: Wydawnictwo Wyższej Szkoły Policji, 1993.

Litwiński Robert, Korpus policji w II Rzeczypospolitej. Służba i życie prywatne, Lublin: Wydawnictwo UMCS, 2007.

Matthäus Jürgen, Historiography and the Perpetrators of the Holocaust [w:] The Historiography of the Holocaust, red. Dan Stone, New York: Palgrave Macmillan, 2005.

Misiuk Andrzej, Policja Państwowa 1919-1939. Powstanie, organizacja, kierunki działania, Warszawa: Wydawnictwo Naukowe PWN, 1996.

Policja granatowa w Generalnym Gubernatorstwie w latach 1939-1945, red. Edyta Majcher-Ociesa, Tomasz Domański, Kielce: IPN, 2019.

Przybyłowicz Krzysztof, Żydzi Biecza. Historia i zagłada, Tuchów: Mała Poligrafia Redemptorystów, 2015.

Radchenko Yuri, We Emptied Our Magazines into Them. The Ukrainian Auxiliary Police and the Holocaust in Generalbezirk Charkow, 1941-1943, „Yad Vashem Studies” 2013, t. 41, nr 1.

Rączy Elżbieta, Pomoc Polaków dla ludności żydowskiej na Rzeszowszczyźnie 1939-1945, Rzeszów: IPN, 2008.

Rembek Stanisław, Wyrok na Franciszka Kłosa, Warszawa: Pax, 1977.

Rich Ian, Holocaust Perpetrators of the German Police Battalions. The Mass Murder of Jewish Civilians, 1940-1942, London: Bloomsbury Academic, 2018.

Roseman Mark, The Lives of Others - Amid the Deaths of Others: Biographical Approaches to Nazi Perpetrators, „Journal of Genocide Research" 2013, t. 15, nr 4.

Salsitz Norman, Kaish Stanley, Three Homelands: Memories of a Jewish Life in Poland, Israel, and America, Syracuse: Harvard University Press, 2002.

Salsitz Norman, Salsitz Amalie P., Against All Odds: A Tale of Two Survivors, New York: Holocaust Library, 1990.

Snyder Timothy, Collaboration in the Bloodlands, odpowiedź na recenzje Johna Connelly'ego, Marka Rosemana, Andriya Portnova i Michaela David-Foxa, zebrane jako: 
Bloodlands: Europe between Hitler and Stalin by Timothy Snyder, „Journal of Genocide Research" 2011, t. 13, nr 3.

Snyder Timothy, Czarna ziemia. Holokaust jako ostrzeżenie, tłum. Bartłomiej Pietrzyk, Kraków: Znak, 2015.

Sokół Jan, Konspiracja nad Wisłą i Sanem, Warszawa: Ludowa Spółdzielnia Wydawnicza, 1976.

Stoll Katrin, Traces of the Holocaust in Nachman Blumental's Archive. The Murder of Maria and Ariel Blumental in Wielopole Skrzyńskie during the German Occupation, „Yad Vashem Studies" 2021, t. 49, nr 2 (w przygotowaniu).

Szopa Piotr, Funkcjonariusze Policji Polskiej Generalnego Gubernatorstwa w wschodnich powiatów Dystryktu Kraków w służbie Polskiego Państwa Podziemnego. Wybrane przykłady [w:] W służbie państwu i społeczeństwu: z dziejów formacji policyjnych na Podkarpaciu (1919-2019), Rzeszów: IPN, 2019.

Szopa Piotr, „W imieniu Rzeczypospolitej...” Wymiar sprawiedliwości Polskiego Państwa Podziemnego na terenie Podokręgu AK Rzeszów, Rzeszów: IPN, 2014.

Szopa Piotr, Zbrodnia katyńska 1940. Pamięci mieszkańców powiatu strzyżowskiego zamordowanych przez Sowietów w Katyniu, Charkowie i Twerze (Kalininie), Rzeszów: IPN, 2010.

Szymańska-Smolkin Sylwia, „Fateful Decisions: The Polish Policemen and the Jewish Population in Occupied Poland, 1939-1944", rozprawa doktorska, University of Toronto, 2017. 